\title{
Passive Q-Switching and Mode-Locking for the Generation of Nanosecond to Femtosecond Pulses
}

\author{
A. Penzkofer \\ Naturwissenschaftliche Fakultät II - Physik, Universität, D-8400 Regensburg, \\ Fed. Rep. Germany
}

Received 2 December 1987/Accepted 8 January 1988

\begin{abstract}
The passive and hybrid Q-switching and mode-locking of solid-state lasers, dye lasers, semiconductor lasers and gas lasers is reviewed. The dynamics of saturable absorbers and reverse saturable absorbers is illustrated. The nanosecond pulse generation by passive and hybrid Q-switching of low-gain active media is described. The picosecond and femtosecond pulse generation by passive and hybrid mode-locking in low-gain and highgain active media is analysed. The performance data of passively and hybridly mode-locked $\mathrm{cw}$ femtosecond dye lasers are collected. The pulse shortening of ultra-fast pulses with saturable absorbers in intra-cavity and extra-cavity configurations is discussed.
\end{abstract}

PACS: 42.55

The photonic switching of lasers provides an important technique to generate short light pulses in the nanosecond to femtosecond time regime. The photons generated in the laser modify the transmission of the switching elements and cause the formation of short pulses. Saturable absorbers serve as intensity or energy dependent coupling elements in most cases. But occasionally intensity and energy-dependent refractive index changes have been applied.

Nanosecond light pulses are generated in passively Q-switched lasers. The passive mode-locking of laser leads to the generation of nanosecond, picosecond or femtosecond pulse trains. The actual pulse durations depend on the spectroscopic data of the active media and of the passive elements.

The nonlinear response of absorbers to light radiation is introduced in the next section [1-9]. The passive, and the hybrid Q-switching are discussed in Sect. 2 [10-12]. The passive, and the hybrid modelocking are described in Sect. 3. A distinction is made between the mode-locking of low-gain [13-34] and high-gain active media [35 45]. The simultaneous Qswitching and mode-locking is discussed shortly in Sect. 4. A final section is devoted to the intra-cavity and extra-cavity pulse shortening with saturable absorbers [46-50].

\section{Absorbers}

The nonlinear absorbers may be dyes in liquids or solids, molecular gases, color centers, or semiconductors. The passage of a light pulse through a nonlinear absorber leads to a pulse shaping, as illustrated in Fig. 1a. The absorption dynamics may be discussed by a four-level system, as depicted in Fig. 1b. The incident photons excite molecules from the ground state 1 to an excited state 2 (ground-state bleaching). The excited molecules relax fastly to a temporal equilibrium position 3 of the excited state ( $\tau_{F C}$ very short). From level 3 the molecules relax to the ground state with an absorption recovery time constant $\tau_{A}$. During the stay of the molecules in levels 2 and 3 they may be excited to higher lying states 4 by absorption of incident radiation (excited-state absorption). The relaxation from level 4 to level 3 is generally very short $\left(\tau_{e x} \rightarrow 0\right)$. Saturable absorbers [1 9 ] are characterized by $\sigma_{A}>\sigma_{e x}$ (Fig. 2a and b). For reverse saturable absor- 


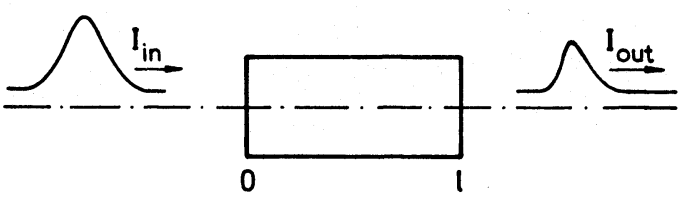

(a)

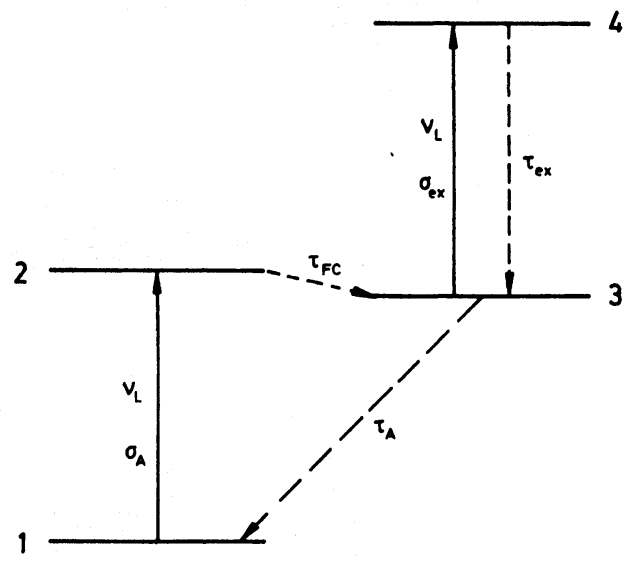

(b)

Fig. 1. (a) Passage of a light pulse through a saturable absorber. (b) Four-level system of absorbers (saturable absorber: $\sigma_{A}>\sigma_{\mathrm{ex}}$; reverse saturable absorber: $\left.\sigma_{A}<\sigma_{\mathrm{ex}}\right)$

bers $[1,51-59]$ the excited-state absorption dominates, i.e. $\sigma_{A}<\sigma_{e x}$ (Figs. $2 \mathrm{c}$ and d).

Fast absorbers have a recovery time $\tau_{A}$ short compared to the laser pulse duration $\Delta t_{L}$ and to the cavity round-trip time $t_{R}$ of the lasers. The transmission through a fast absorber is given roughly by [8]

$$
\begin{aligned}
T & =\frac{I_{\text {out }}}{I_{\text {in }}} \simeq \exp \left(-\sigma_{A} N_{1} l-\sigma_{e x} N_{3} l\right) \\
& \simeq \exp \left(-\sigma_{A} \frac{N_{0}}{1+I_{\text {in }} / I_{S}^{A}} l-\sigma_{\mathrm{ex}} \frac{N_{0}}{1+I_{S}^{A} / I_{\mathrm{in}}} l\right) .
\end{aligned}
$$

$N_{0}$ is the total number density of absorber molecules. $I_{S}^{A}$ is the saturation intensity. Its value is

$I_{S}^{A}=\frac{h v_{L}}{\sigma_{A} \tau_{A}}$

Equation (2) is valid for $\tau_{F C} \ll \tau_{A}$ [2].

The nonlinear transmission and the pulse shaping of a fast saturable absorber are illustrated in Figs. $2 a$ and $a^{\prime}[48]$. The leading and trailing part of the pulse are absorbed preferentially. The light pulses are shortened by the passage through the absorber cell. Fast saturable absorbers are applied mainly for modelocking of low-gain lasers (solid-state lasers, $\mathrm{CO}_{2}$ lasers, iodine lasers).
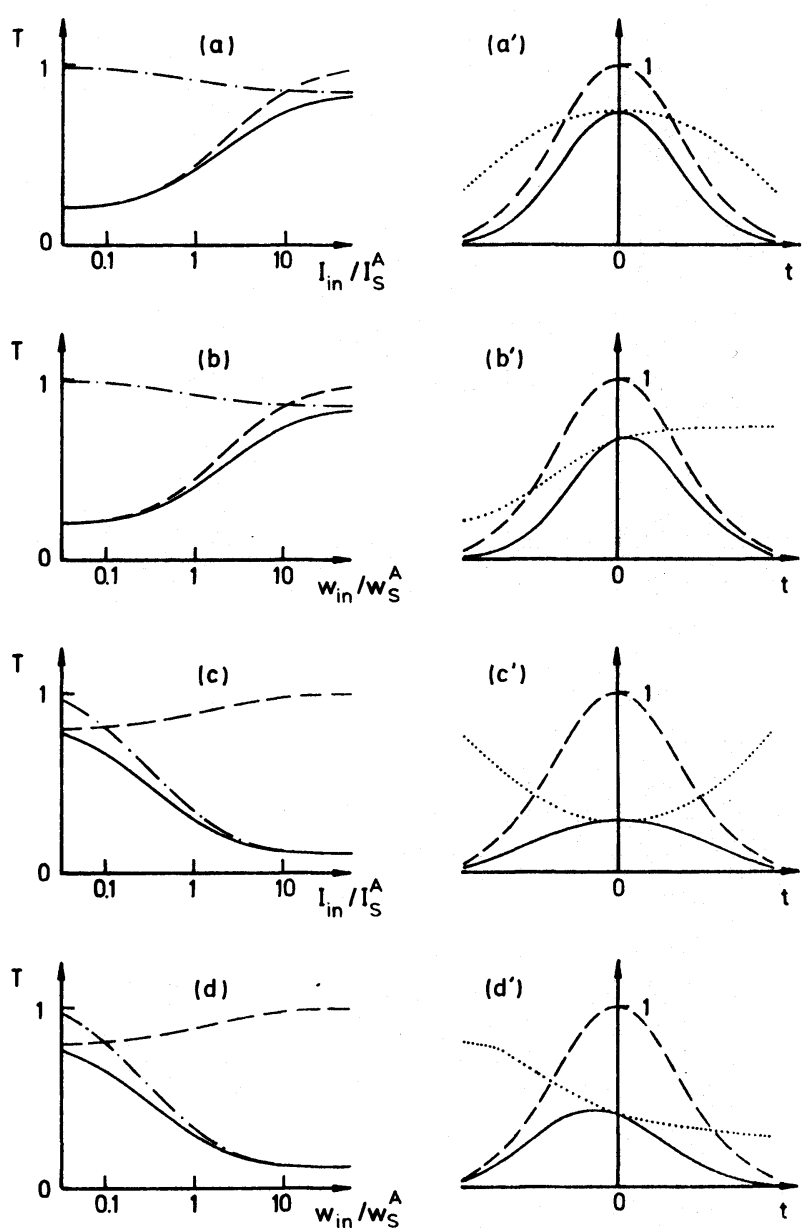

Fig. 2. Transmission behaviour and pulse shaping of absorbers. Left half: Nonlinear transmissions $T$. Dashed curves, groundstate absorption (transition 1-2); dash-dotted curves, excitedstate absorption (transition 3-4); solid curves, total transmission. Right half: Dashed curves, normalized incident pulses $I_{\mathrm{in}}(t) / I_{\mathrm{in}, 0}$; solid curves, transmitted pulses $I_{\mathrm{out}}(t) / I_{\mathrm{in}, 0}$. Dotted curves represent temporal transmissions $T(t) . \quad I_{\text {in }}=I_{\text {in }}(t) ; \quad I_{\text {in. } .0}=I_{\text {in }}(0)$; $w_{\text {in }}=\int_{-\infty}^{t} I_{\text {in }}\left(t^{\prime}\right) d t^{\prime} ; w_{\text {in }, 0}=\int_{-\infty}^{\infty} I_{\text {in }}\left(t^{\prime}\right) d t^{\prime}$. (a) and $\left(\mathrm{a}^{\prime}\right)$ Fast saturable absorber $\left(\sigma_{\mathrm{ex}} / \sigma_{A}=0.1 ; I_{\mathrm{in}, 0}=10 \times I_{S}^{A}\right)$. (b) and ( $\left(\mathrm{b}^{\prime}\right)$ Slow saturable absorber $\left(\sigma_{\mathrm{ex}} / \sigma_{A}=0.1 ; w_{\mathrm{in}, 0}=10 \times w_{S}^{A}\right)$. (c) and (c') Fast reverse saturable absorber $\left(\sigma_{\mathrm{ex}} / \sigma_{A}=10 ; I_{\mathrm{in}, 0}=I_{S}^{A}\right)$. (d) and (d') Slow reverse saturable absorber $\left(\sigma_{\mathrm{ex}} / \sigma_{A}=10 ; w_{\mathrm{in}, 0}=w_{S}^{A}\right)$

The transmission and the pulse shaping of a fast reverse saturable absorber are shown in Figs. $2 \mathrm{c}$ and $\mathrm{c}^{\prime}$. The input pulses are broadened in the absorber. Fast reverse saturable absorbers may bc applied for power limiting [59].

Slow absorbers have a recovery time $\tau_{A}$ which is long compared to the laser pulse duration $\Delta t_{l}$. The light transmission through a slow absorber is approximately given by [8]

$T \simeq \exp \left(-\sigma_{A} \frac{N_{0}}{1+w_{\mathrm{in}} / w_{S}^{A}} l-\sigma_{\mathrm{ex}} \frac{N_{0}}{1+w_{S}^{A} / w_{\mathrm{in}}} l\right)$, 
$w_{S}^{A}$ being the saturation energy density $\left[\mathrm{J} / \mathrm{cm}^{2}\right]$. Its value is

$w_{S}^{A}=\frac{h v_{L}}{\sigma_{A}}$.

The transmission and pulse shaping behaviour of a slow saturable absorber are depicted in Figs. $2 b$ and $b^{\prime}$. The light pulses are shortened at the leading part. Slow saturable absorbers are suitable for passive Q-switching of lasers, and they are often used for passive mode-locking of high-gain lasers (dye lasers, color-center lasers, semiconductor lasers, excimer lasers, $\mathrm{He}-\mathrm{Ne}$ lasers, $\mathrm{Ar}^{+}$lasers).

The transmission and pulse forming of slow reverse saturable absorbers are shown in Figs. $2 d$ and $d^{\prime}$. The absorption is increased in the trailing part of the pulses. For the depicted Gaussian input pulse shape the slow reverse saturable absorber broadens the output pulse somewhat $\left(\Delta t_{\text {out }}>\Delta t_{\text {in }}\right)$. Input pulses of rectangular temporal shape would be shortened. The combined application of a saturable absorber and a slow reverse saturable absorber is thought to improve the pulse shortening $[55,57]$.

\section{Passive Q-Switching}

In Q-switched lasers the resonator losses are changed from high values (low-quality factor $Q$ ) to low values (high Q-value) after the pump pulse energy has been accumulated for a sufficient time in the active medium. The switching to a high Q-value brings the laser far above threshold. The resulting high net gain generates a steeply rising intense pulse. The end of the laser action is due to the depletion of the upper laser level [10-12, 60-63]. The steepness of the trailing edge of the generated pulse is determined by the photon-lifetime of the cavity, $\tau_{\text {cav }} \simeq t_{R} / \ln (R 2)$ (trailing half width $\geqq$ roundtrip time $t_{R}, R 2$ is the reflectivity of output mirror M2) [63].

The storage time of the pump pulse energy in the active medium is limited by the upper laser level lifetime $\tau_{G}$. Only low-gain active media have long upper laser level lifetimes and are suitable for Q-switched laser operation (ruby: $\tau_{G} \simeq 3 \mathrm{~ms}$; Nd:YAG: $\tau_{G} \simeq 250 \mu \mathrm{s}, \mathrm{Nd}$ : glass: $\tau_{G} \simeq 350 \mu \mathrm{s}$, alexandrite: $\tau_{G} \simeq 50 \mu \mathrm{s}$ [63], $\mathrm{CO}_{2}: \tau \approx 1 \mathrm{~ms}$ for $p \simeq 1 \mathrm{mbar}$ [61]). The energy storage capacity is limited approximately to the saturation energy density, $w_{S}^{G}=h v_{L} / \sigma_{G}$, by the onset of amplified spontaneous emission [63] (ruby:

$\sigma_{G}=2.5 \times 10^{-20} \mathrm{~cm}^{2}, \lambda_{L}=694.3 \mathrm{~nm}, w_{S}^{G}=11.4 \mathrm{~J} / \mathrm{cm}^{2} ;$

$\mathrm{Nd}: \mathrm{YAG}$ :

$\sigma_{G}=8.8 \times 10^{-19} \mathrm{~cm}^{2}, \lambda_{L}=1.064 \mu \mathrm{m}, w_{S}^{G}=0.21 \mathrm{~J} / \mathrm{cm}^{2}$;
$\mathrm{Nd}$ : glass:

$\sigma_{G} \simeq 4 \times 10^{-20} \mathrm{~cm}^{2}, \lambda_{L}=1.055 \mu \mathrm{m}$,

$w_{S}^{G}=4.5 \mathrm{~J} / \mathrm{cm}^{2}$;

alexandrite:

$\left.\sigma_{G}=7 \times 10^{-21} \mathrm{~cm}^{2}, \lambda_{L}=750 \mathrm{~nm}, w_{S}^{G}=38 \mathrm{~J} / \mathrm{cm}^{2}\right)$.

High-gain active media (large $\sigma_{G}$, small $\tau_{G}$ ) are not suitable for Q-switching. For these media cavity dumping is used to generate intense short pulses [64].

Passive Q-switching is achieved generally with saturable absorbers in the laser oscillator. Slow saturable absorbers are more convenient than fast saturable absorbers. Refractive-index changes may also be applied to Q-switching [65]. The passive Q-switching has been combined with active Q-switching (hybrid Q-switching) [66-68].

\subsection{Passive Q-Switching with Saturable Absorbers}

The schematic of a passively Q-switched laser is shown in Fig. 3a. The laser consists of the active medium, the saturable absorber and a frequency narrowing or tuning element. The Q-switch operation is explained by the Figs. $3 b-e$. The excitation pulse of pump rate $J$ (Fig. 3b, dimension of photons $\mathrm{cm}^{-3} \mathrm{~s}^{-1}$, or $\mathrm{W} \mathrm{cm}^{-3}$ ) populates the upper laser level (Fig. 3c). As soon as the upper laser level population $N_{u}$ crosses the low-Q threshold population $N_{t h}^{L Q}$, laser action sets in. If the intensity of the generated laser radiation approaches the saturation intensity of the absorber, the losses in the resonator are reduced, the laser-threshold population lowers to $N_{t h}^{H Q}$, and strong amplification of the radiation occurs. The generated radiation depletes the upper laser level population rapidly and terminates the laser action. If the generated pulse is not intense enough to approach the absorber saturation intensity $I_{S}^{A}$, the laser remains at the low-Q threshold and a damped laser spiking occurs. Focusing of the laser radiation into the saturable absorber cell may be employed to achieve Q-switching.

For long pump pulses or continuous pumping a repetitive Q-switching occurs $[69,85]$. The temporal spacing between the Q-switched pulses is shortened with rising pump power.

Slow saturable absorbers $\left(\tau_{A}\right.$ in the $n s$ region) have low saturation intensities and facilitate the Q-switching. Fast saturable absorbers in lasers with broad-band active media mode-lock the radiation. The mode-locking is suppressed by spectral narrowing the gain profile with resonance reflectors, Fabry-Perot etalons, birefringent filters, or gratings. The spectral gain narrowing elements may be used for laser frequency tuning within the gain profile of the active medium $[70,71]$. 
(a)
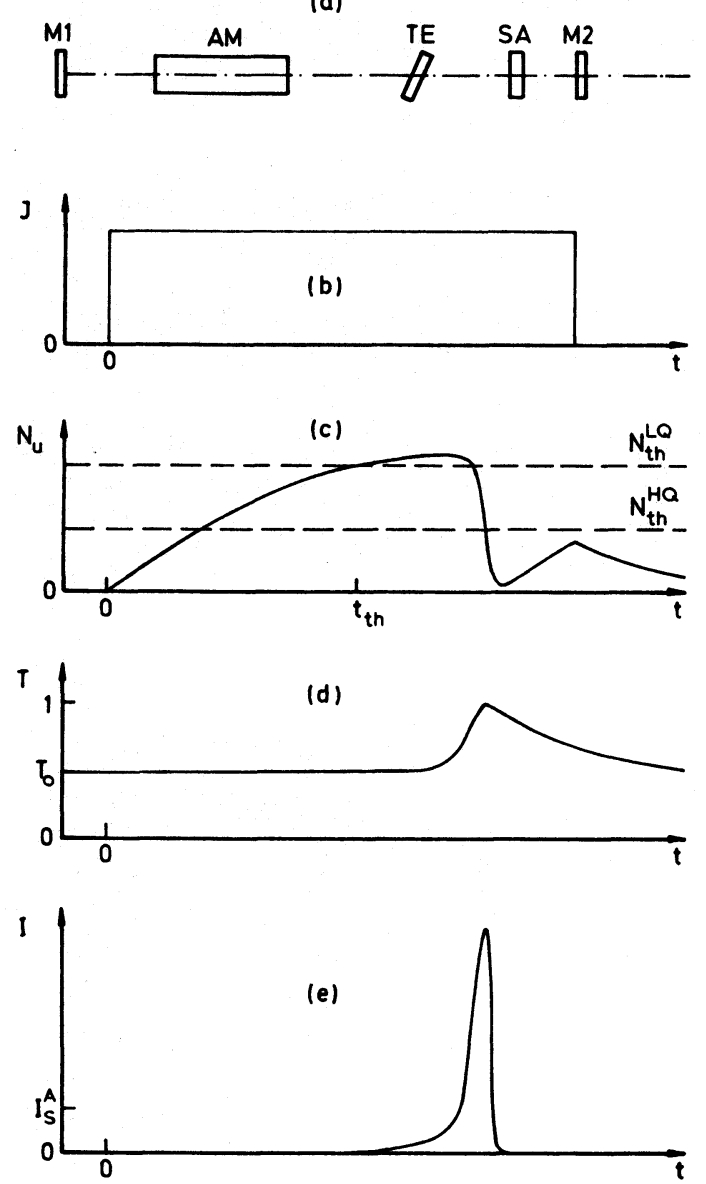

Fig. 3a-e. Passively $Q$-switched laser. (a) Schematic experimental setup. (M1, M2: laser mirrors, AM: active medium. TE: tunning element, SA: saturable absorber). (b) Temporal profile of excitation pulse $J$ (dimension: photons $/ \mathrm{cm}^{3} \mathrm{~s}$ or $\mathrm{W} / \mathrm{cm}^{3}$ ). (c) Upper laser level population $N_{u}$ (solid curve). The dashed curves indicate the low- $Q\left(N_{t h}^{L Q}\right)$ and high- $Q\left(N_{t h}^{H Q}\right)$ laser threshold population. $\left(t_{t h}\right.$ : start of laser action).(d) Temporal transmission through saturable absorber. ( $T_{0}$ : small signal transmission). (e) Temporal pulse development. ( $I_{S}^{A}$ : saturation intensity of absorber)

Short-cavity resonators with low output-coupler reflectivities $\mathbf{R} 2$ and saturable absorbers with absorption recovery times less than the cavity round-trip time $\left(\tau_{A}<t_{R}\right)$ allow the generation of short Q-switched pulses in the time domain around $1 \mathrm{~ns}[72,73]$.

Since the first passive Q-switching of ruby lasers with organic dye solutions [74-76] various solid-state lasers (ruby, alexandrite, Nd:YAG, Nd:glass; pulse durations typical 10-20 ns) and $\mathrm{CO}_{2}$ lasers (pulse duration between $400 \mathrm{~ns}$ and $2 \mu \mathrm{s}$ ) have been Q-switched with different saturable absorbers. References to the various Q-switched lasers are given in Table 1.

The passive Q-switching with saturable absorbers has to compete with active Q-switching [60-63]. The passive Q-switching is simpler and allows the generation of shorter pulses. The active Q-switching with electro-optic shutters has a better shot-to-shot stability and is easy to synchronize with other lasers.

\subsection{Hybrid Q-Switching}

The simultaneous active and passive Q-switching combines the advantages of active and passive Q-switching [66-68]. In [66 and 67] mechanical shutters and organic dyes have been applied to Q-switch ruby lasers. In [68] a hybridly Q-switched $\mathrm{Nd}$ :YAG laser has been described. A rotating roof prism is used for active Q-switching. The passive element is a $F_{2}^{-}: \mathrm{LiF}$ crystal. Multiple pulse generation is avoided by the mechanical switching. Pulses down to $10 \mathrm{~ns}$ duration have been obtained.

\subsection{Passive Q-Switching by Refractive Index Changes}

Besides the application of saturable absorbers for passive Q-switching, the intensity dependent refractive index changes may be employed for Q-switching. In [65] the self-focusing action of a Kerr liquid in an unstable $\mathrm{Nd}$ : glass laser reduces the diffraction losses and changes the configuration to a stable resonator. The loss-reduction causes the Q-switch pulse formation.

\section{Passive Mode-Locking}

Passive mode-locking instead of passive Q-switching occurs under the following conditions: i) the spectral gain width $\Delta v_{G}$ of the active medium is broad $\left(\Delta v_{G} \gg t_{R}^{-1}\right.$, spontaneous emission signal is fluctuating within round-trip time [109]), ii) spectral gain narrowing is avoided, and iii) the saturable absorber recovery time is short compared to the round-trip time $\left(\tau_{A}<t_{R}\right)$ $[110,111]$.

Fast saturable absorbers are needed for low-gain active media. The obtained pulse durations are of the order of the absorption recovery time. In a steady-state system the pulse duration is determined by the balance between pulse shortening (saturable absorber) and pulse broadening (finite spectral width of active medium, power limiting effects $[59,113])[32,112]$.

If $\tau_{A} \ll \Delta v_{G}^{-1} \leqq T_{2}^{G},\left(T_{2}^{G}\right.$ is the phase relaxation time of the active medium) then the coherent light-matter interaction determines the pulse development ( $\pi$-pulse generation, self-induced transparency). For this situation pulses with durations $\Delta t_{L}$ less than the inverse gain width $\Delta v_{G}^{-1}$ have been generated (ruby and $\mathrm{Nd}$ :YAG at low temperature) [114-116]. 
Table 1. Passively Q-switched lasers

\begin{tabular}{|c|c|c|}
\hline Active medium & Absorber & Ref. \\
\hline Ruby $\lambda_{L}=694.3$ & $\begin{array}{l}\text { Liquid organic dye solutions } \\
\text { Organic dyes in polymers } \\
\text { Semiconductor glasses } \\
\text { (edge filters) } \\
\text { Color centers in ruby }\end{array}$ & $\begin{array}{l}{[72,74-86]} \\
{[79,85]} \\
{[78,79,87]} \\
{[85]}\end{array}$ \\
\hline Alexandrite $\lambda_{L}=$ & $\begin{array}{l}783 \mathrm{~nm} \\
\text { Color center }\left(\left(\mathrm{F}_{2}^{+}\right)_{A} \mathrm{NaF}: \mathrm{Li}\right)\end{array}$ & {$[70]$} \\
\hline $\mathrm{Nd}:$ YAG $\lambda_{L}=1$ & $\begin{array}{l}\text { Liquid organic dye solutions } \\
\text { Organic dyes in polymers } \\
\text { Color centers }\left(\mathrm{F}_{2}^{-}: \mathrm{LiF}\right)\end{array}$ & $\begin{array}{l}{[88-91]} \\
{[73,92,93]} \\
{[68,69,94,95]}\end{array}$ \\
\hline $\mathrm{Nd}$ : Glass $\lambda_{L} \simeq 1$ & $\begin{array}{l}\text { Liquid organic solutions } \\
\text { Color centers }\left(\mathrm{F}_{2}^{-}: \mathrm{LiF}\right)\end{array}$ & $\begin{array}{l}{[89-91]} \\
{[96,97]}\end{array}$ \\
\hline $\begin{array}{r}\mathrm{CO}_{2} \lambda_{L} \text { around } \\
\lambda_{L} \text { around }\end{array}$ & $\begin{array}{l}n \\
\text { Organic gases }\left(\mathrm{CF}_{2} \mathrm{Cl}_{2}, \mathrm{HCOOH}\right) \\
\text { Organic gases }\left(\mathrm{CH}_{3} \mathrm{~F}, \mathrm{CH}_{3} \mathrm{OH},\right. \\
\left.\mathrm{HCOOH}, \mathrm{C}_{3} \mathrm{H}_{4}, \mathrm{CH}_{3} \mathrm{Cl}, \mathrm{C}_{2} \mathrm{~F}_{3} \mathrm{Cl}\right)\end{array}$ & $\begin{array}{l}{[99,102]} \\
{[99-101]} \\
{[103,105]}\end{array}$ \\
\hline$\lambda_{L}$ around & $\begin{array}{l}\text { Organic gases }\left(\mathrm{SF}_{6}, \mathrm{PF}_{5} \text {, }\right. \\
\mathrm{CH}_{2}=\mathrm{CHCl}, \mathrm{BCl}_{3}, \mathrm{CF}_{2} \mathrm{Cl}_{2} \text {, } \\
\mathrm{CO}_{2} \text {-propylene } \\
\text { Color center }\left(\mathrm{ReO}_{3}^{-}: \mathrm{KCl}\right)\end{array}$ & $\begin{array}{l}{[98,99,104,} \\
{[106,107]} \\
{[108]}\end{array}$ \\
\hline
\end{tabular}

For high-gain active media slow saturable absorbers are sufficient for short pulse generation, since the leading part is shortened by the absorber and the trailing part is shortened by the gain medium [18]. A detailed analysis indicates the following requirements for the passive mode-locking of high-gain lasers $[18,117]$ : i) the absorber has to saturate more easily than the gain medium in order to provide a net gain at the peak of the pulse and loss on either side. This condition requires $\sigma_{A} / A_{A}>\sigma_{G} / A_{G}$ where $A_{A}$ and $A_{G}$ are the laser beam cross-sections at the absorber and the gain medium, respectively. ii) The absorption recovery time of the saturable absorber $\tau_{A}$ has to be faster than the gain recovery time $\tau_{G}$ (equal to upper laser level lifetime) of the gain medium, i.e. $\tau_{A}<\tau_{G}$. This condition garanties the background suppression between the circulating pulse. iii) The absorption recovery time has to be less than the cavity round-trip time $\left(\tau_{A}<t_{R}\right)$, otherwise a steady-state continuous emission would result after damped spiking.

The passive mode-locking may be combined with various methods of active mode-locking [118-123, 320]. Instead of absorption changes the intensity dependent refractive index may be applied to passive mode-locking [121, 124-130].

\subsection{Passive Mode-Locking with Saturable Absorbers}

The passive mode-locking in low-gain lasers and highgain lasers is discussed separately.

a) Low-Gain Active Media. Passive mode-locking of lasers having low-gain active media (solid-state lasers [138-159], iodine lasers [166,167], TEA-CO $\mathrm{CO}_{2}$ lasers $[43,108,162])$ is illustrated in Fig. 4. In part (a) a linear oscillator is shown. The saturable absorber is located near a laser mirror. More often the absorber is contacted directly to a mirror (colliding pulse arrangement) [131] in order to increase the laser intensity in the absorber and to avoid the appearance of satelite pulses. Sometimes the colliding pulse arrangement is formed by placing the saturable absorber midway in the resonator [132] or in an antiresonant ring $[133,134]$.

The pictures (b) to (e) of Fig. 4 illustrate the mechanism of mode-locking (passive loss modulation). The left half characterizes an early stage of pulse development. The right half depicts the steady-state situation. Due to the low gain of the active medium the upper laser level population $N_{u}$ remains practically constant within a round-trip period $t_{R}$ in the case of 


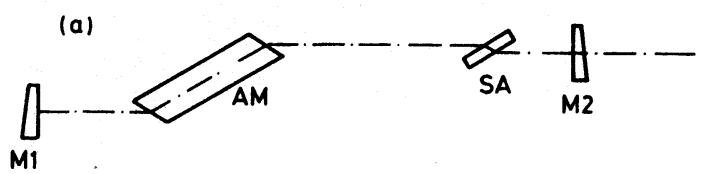

了

(b)
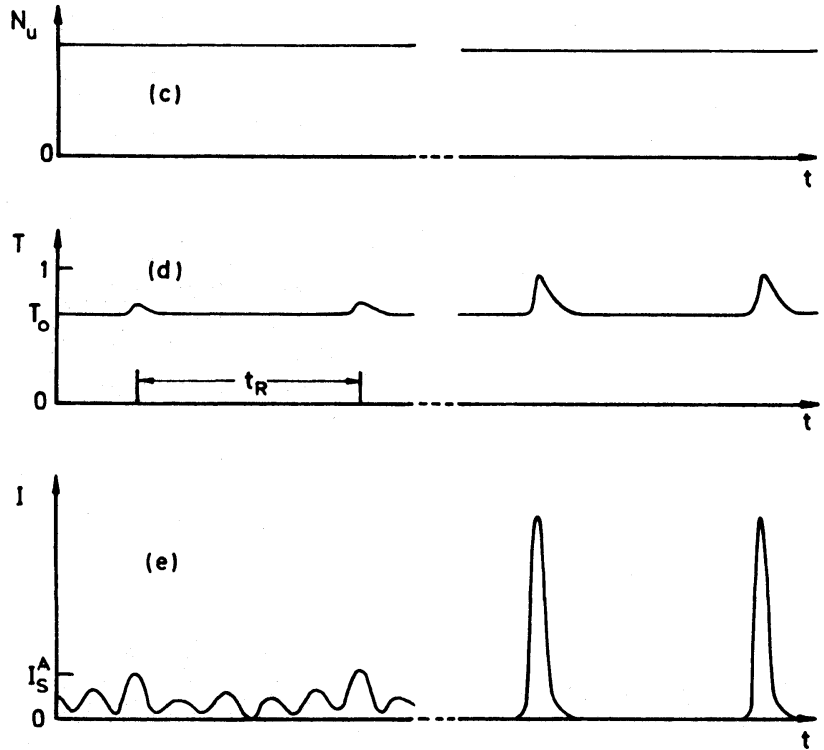

Fig. 4a-e. Passively mode-locked low-gain laser. (a) Schematic of a linear resonator setup. (M1, M2: laser mirrors, AM: active medium, SA: saturable absorber).(b) Pump rate J. (c) Upper laser level population. (d) Saturable absorber transmission. (e) Temporal pulse development. (b-e) Left half: early stage of pulse development. Right half: steady-state performance. $t_{R}$ is the resonator round-trip time

constant pumping $J$. The transmission $T$ of the saturable begins to increase as soon as a spike of the circulating radiation approaches the saturation intensity of the absorber. The small signal transmission is restored with the absorption recovery time $\tau_{A}$. In the steady-state situation the amplification of the circulating radiation reduces the upper laser level population density (right side of Fig. 4c compared to left side). The population is below the threshold population for the small signal transmission $T_{0}$. Only the strongest spike survives. The radiation between the circulating pulse is suppressed.

In flashlamp-pumped passively mode-locked lasers, the pulse intensity often rises far above the saturation intensity $\left(I_{L} \gg I_{S}\right)$ and the pulse shortening action is lost. In this case the nonlinear transmission period is too short to approach the steady-state situation, and the pulse duration remains longer than the steady-state limit. A linear loss feedback may keep the mode-locked pulse intensity in the nonlinear transmission region, prolong the pulse train length, and shorten the pulses down to the steady-state limit [112, 135-137].

The passive mode-locking is widely used for picosecond pulse generation with $\mathrm{Nd}$ :glass [15-17, 22, 29-32, 138-151, 186], Nd:YAG [133, 134, 149-152], and ruby lasers [22, 153-159]. It has also been successfully applied to mode-lock tunable solid-state lasers (alexandrite $[132,160]$ ) and sensitized solidstate lasers (Nd:Cr:GSGG [161]). Atmospheric TEA-CO $\mathrm{CO}_{2}$ lasers allow the generation of subnanosecond pulses by passive mode-locking with saturable semiconductors (p-type $\mathrm{Ge}[162])$, color centers $\left(\mathrm{ReO}_{4}^{-}: \mathrm{KCl}\right.$ [108]) and molecular gases $\left(\mathrm{SF}_{6}\right.$ [162]) (for a review, see [43]). HeNe lasers have been modelocked with $\mathrm{Ne}\left(\Delta t_{L} \simeq 330 \mathrm{ps}\right)$ [164] and various saturable dyes $\left(\Delta t_{L} \simeq 220 \mathrm{ps}\right)$ [165] (for a review, see [43]). Iodine photodissociation lasers $\left(\lambda_{L}=1.3152 \mu \mathrm{m}\right)$ have been mode-locked mainly with the saturable dye BDN II $\left(\Delta t_{L} \simeq 1.7 \mathrm{~ns}\right)[166,167]$. Newly developed infrared dyes (S 301, S 401, S 501) [168] should be suitable to mode-lock iodine lasers.

It should be noted that the saturation intensity $I_{S}^{A}$ is inversely proportional to the absorption recovery time $\tau_{A}$. For very fast saturable absorbers the mode-locking threshold is difficult to approach since the peak spiking intensity of the laser remains below the saturation intensity [32] and special focusing geometries are necessary to achieve mode-locking $[147,170]$. The use of two saturable absorbers of widely different saturation intensity (different $\tau_{A}$ ) offers the possibility of low mode-locking threshold and short pulse generation [112,171].

The high saturation intensity restricts generally the passive mode-locking to pulsed laser systems. Passive mode-locking of $\mathrm{cw} \mathrm{Nd:YAG} \mathrm{lasers} \mathrm{with} \mathrm{an} \mathrm{organic}$ dye [172] and an $\mathrm{F}_{2}^{+}$-center [173] has been reported.

The generation of intensive picosecond light pulses is often accompanied by self-phase modulation which causes broad-band chirped pulses [174]. The chirped pulses may be compressed by bandwidth-limiting filtering of the active medium $[32,121,159,175-178]$ inside the oscillator or by dispersive effects in grating pairs, prism pairs, or grating-prism combinations outisde the oscillator $[179,180]$.

In Table 2 some data of the most commonly used saturable absorbers for solid-state lasers are collected. Especially for $\mathrm{Nd}$ :lasers a considerable number of organic dyes [181-183] and color centers [173, 184, $185]$ have been investigated. For saturable absorbers with the absorption peak at the short-wavelength side of the laser wavelength only a fraction of molecules takes part in the absorption process. The absorption 
Table 2. Saturable Absorbers for solid-state lasers

\begin{tabular}{|c|c|c|c|c|c|c|}
\hline Absorber & Solvent & $\begin{array}{l}\lambda_{A}^{\max } \\
{[\mathrm{nm}]}\end{array}$ & $\begin{array}{l}\tau_{A} \\
{[\mathrm{ps}]}\end{array}$ & $\begin{array}{l}\sigma_{A} \\
{\left[\mathrm{~cm}^{2}\right]}\end{array}$ & $\begin{array}{l}I_{S}^{A} \\
{\left[\mathrm{~W} / \mathrm{cm}^{2}\right]}\end{array}$ & Ref. \\
\hline \multicolumn{6}{|c|}{ Ruby $\lambda_{L}=694.3 \mathrm{~nm}, \Delta \tilde{v}_{G}=11 \mathrm{~cm}^{-1}, \tau_{G}=3 \mathrm{~ms}$} & {$[187]$} \\
\hline DDI & Methanol & 704 & $17 \pm 3$ & $7.6 \times 10^{-16}$ & $2.2 \times 10^{7}$ & {$[188,189]$} \\
\hline DCI & Ethanol & 704 & $37^{-2}$ & $5.8 \times 10^{-16}$ & $1.3 \times 10^{7}$ & {$[190]$} \\
\hline DCI' $^{\prime}$ & Ethanol & 658 & 20 & & & {$[191]$} \\
\hline DTDCI & Ethanol & 655 & 180 & & & [191] \\
\hline \multicolumn{6}{|c|}{ Alexandrite $\lambda_{L}=701-818 \mathrm{~nm}, \tau_{G}=262 \mu \mathrm{s}$} & [203] \\
\hline $\operatorname{DDI}\left(\lambda_{L}=745 \mathrm{~nm}\right)$ & Ethanol & 709 & & & & [204] \\
\hline DCI $\left(\lambda_{L}=740 \mathrm{~nm}\right)$ & Ethanol & 709 & 37 & & & [204] \\
\hline $3501 u\left(\lambda_{L}=750-780 \mathrm{~nm}\right)$ & Ethanol & 732 & & & & [204] \\
\hline $4183 u\left(\lambda_{L}=750-780 \mathrm{~nm}\right)$ & Ethanol & 722 & & & & [204] \\
\hline \multirow{3}{*}{\multicolumn{6}{|c|}{$\begin{array}{l}\mathrm{Nd}: \text { glass: } \lambda_{L} \simeq 1.055 \mu \mathrm{m}, \Delta \tilde{v}_{G} \simeq 200 \mathrm{~cm}^{-1}, \tau_{G} \simeq 350 \mu \mathrm{s} \\
\mathrm{Nd}: Y A G: \lambda_{L}=1.064 \mu \mathrm{m}, \Delta \tilde{v}_{G} \simeq 4.5 \mathrm{~cm}^{-1}, \tau_{G} \simeq 250 \mu \mathrm{s} \\
\mathrm{Nd}: \mathrm{Cr}: G S G G: \lambda_{L}=1.0613 \mu \mathrm{m}, \Delta \tilde{v}_{G} \simeq 12 \mathrm{~cm}^{-1}, \tau_{G} \simeq 250 \mu \mathrm{s}\end{array}$}} & [32] \\
\hline & & & & & & {$[192]$} \\
\hline & & & & & & [193] \\
\hline A 9860 & 1,2-Dichloroethane & 1066 & 7 & $3.7 \times 10^{-16}$ & $7.3 \times 10^{7}$ & {$[194,195,196]$} \\
\hline A 9740 & 1,2-Dichloroethane & 1060 & 11 & $6.1 \times 10^{-16}$ & $2.8 \times 10^{7}$ & {$[194,196]$} \\
\hline IR 5 & 1,2-Dichloroethane & 1090 & 2.7 & $3 \times 10^{-16}$ & $2.3 \times 10^{8}$ & {$[195,196]$} \\
\hline BDNI & Diethyl sulfide & 1060 & $25 \sim$ & $\sim 1.1 \times 10^{-16}$ & $6.8 \times 10^{7}$ & {$[92,198]$} \\
\hline 3955 & Nitrobenzene & 1040 & $75,44 *$ & $3.2 \times 10^{-16}$ & $7.9 \times 10^{6}$ & {$[199,200,182]$} \\
\hline 3955 & Methanol & & 35 & & & [199] \\
\hline $3274-u$ & Nitrobenzene & 1086 & 14 & $7.2 \times 10^{-16}$ & $1.9 \times 10^{7}$ & {$[183,182]$} \\
\hline $3274-u$ & Methanol & & 6 & & & {$[183]$} \\
\hline $3321-u$ & Nitrobenzene & 1134 & 0.35 & $2 \times 10^{-16}$ & $2.7 \times 10^{9}$ & {$[147,182]$} \\
\hline 4363 & Polyurethane acrylate & 1067 & 6 & & & {$[152]$} \\
\hline$Z$ color center & $\mathrm{Ba}, \mathrm{Eu}, \mathrm{Sr}: \mathrm{RbBr}$ & & $\sim 50$ & $10^{-18}-10^{-17}$ & $3 \times 10^{8}-3 \times 10^{9}$ & [205] \\
\hline
\end{tabular}

$\mathrm{DDI}=1,1^{\prime}$-diethyl-2,2'-dicarbocyanine iodide $=$ DDCI

$\mathrm{DCI}=1,1^{\prime}$-diethyl-4,4'-carbocyanine iodide-cryptocyanine

$\mathrm{DCI}^{\prime}=1,1^{\prime}$-diethyl-2,4'-carbocyanine iodide $=$ DCCI

DTDCI $=3,3^{\prime}$-diethyl-2,2'-thiadicarbocyanine iodide

cross-section of the interacting molecules is approximately equal to the stimulated emission cross-section at the laser frequency [201,202].

b) High-Gain Active Media. The passive modelocking of high-gain active media (dye lasers [22, 208, $211,212]$, diode lasers [117, 270-272], excimer lasers [273-278], color-center lasers [207], HeNe lasers [43, 164, 165], $\mathrm{Ar}^{+}$lasers [169]) is illustrated in Fig. 5. Part (a) depicts a cw laser pumped colliding pulse mode-locked ring laser (CPM laser) [206]. This oscillator layout is used especially for femtosecond pulse generation in organic dyes [206] and color centers [207]. Linear resonators, like the arrangement of Fig. 4a, are in operation for pulsed and cw dye lasers, diode lasers, and excimer lasers. A comparison of Figs. $5 \mathrm{c}$ and $4 \mathrm{c}$ indicates the difference between highgain and low-gain media. In the high-gain media the gain is saturated by the most intense fluctuation. The upper laser-level population falls below the threshold population in the trailing part of the circulating pulse. Slow saturable absorbers (Fig. 5d) are sufficient for mode-locking [18, 36, 37, 40, 41]. From the spontaneous emission (Fig. 5e, left half) the most intense
* M.A. Vasil'eva, J. Vishchakas, V. Gulbinos, V.I. Malyshev, A.V. Masalov, V. Kabelka, and V. Syrus, IEEE J. QE-19 (1983) 724.

fluctuation survives and circulates in the oscillator (right half).

Passively mode-locked dye lasers may be pumped by flashlamps, pulsed lasers, or cw lasers (argon-ion lasers, krypton-ion lasers) [22, 43, 208].

The passive mode-locking was first achieved in a flashlamp-pumped rhodamine $6 \mathrm{G}$ laser with the saturable absorber DODCI [209]. The flashlamp-pumped organic dye laser oscillators generate intense, frequency tunable, light pulses of several picoseconds duration and several tens of megawatt power $[22,208,210$, 211]. Using different lasing dyes and saturable absorbers passive mode-locking has been achieved in the wavelength region between 450 and $840 \mathrm{~nm}$. [Ref. 212, Table 2.1] gives an overview of the covered spectral region (references are cited there). The passive mode locking of flashlamp-pumped dye lasers has been reviewed in [22, 208, 211,212]. Data on lasing dyes and saturable absorbers have been collected in $[213,214]$.

Passive mode-locking with pulsed pump lasers has been discussed in $[215,216]$. In a colliding pulse ring arrangement pulses of $340 \mathrm{fs}$ duration were generated using $100 \mu$ s long pulses of a xenon ion pump laser (lasing dye rhodamine 6G, absorber DODCI) [216]. 
(a)

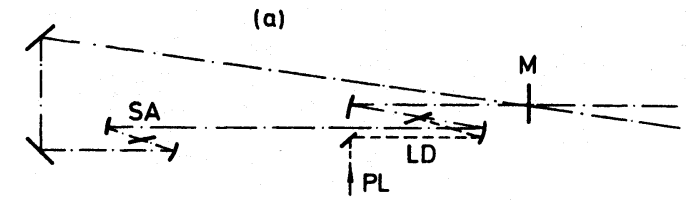

了
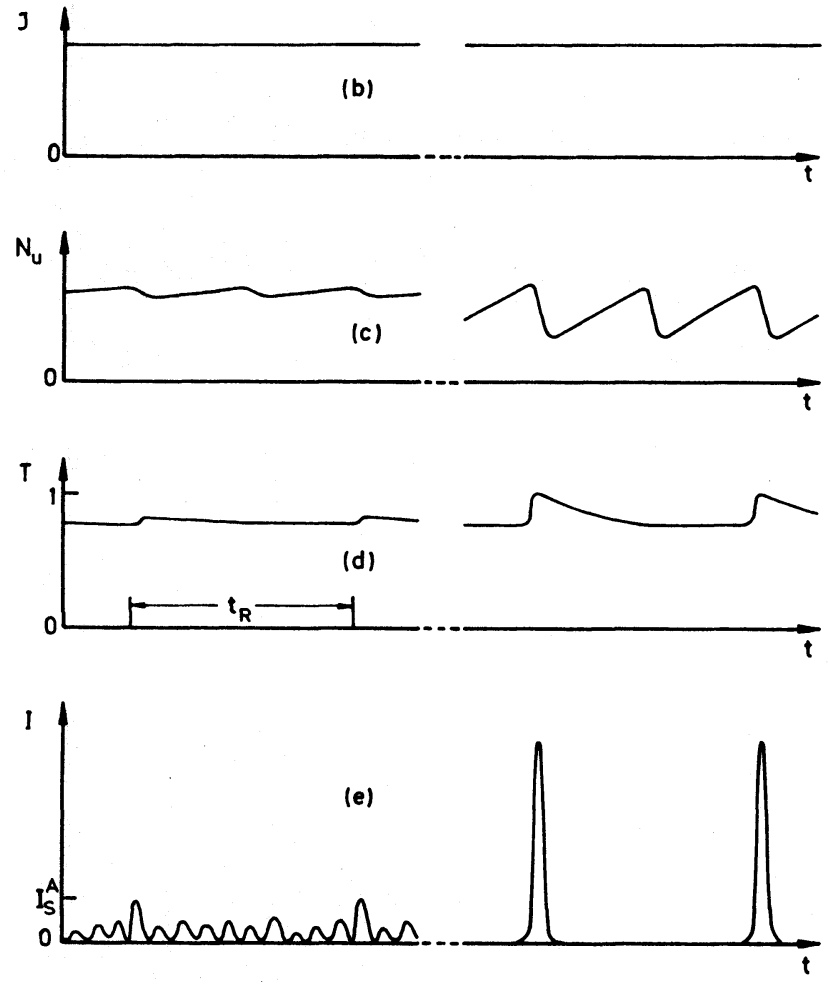

Fig. 5a e. Passively mode-locked high-gain laser. (a) Schematic setup of a CPM ring laser. (PL: pump laser, LD: lasing dye jet, SA: saturable absorber jet, $M$ : output coupler).(b) Pump rate $J$. (c) Population of upper laser level. The two counter-propagating pulses pass through the active medium at time intervals of $t_{R} / 2$. (d) Saturable absorber transmission. (e) Temporal pulse development. (b-e) Left half: early stage of pulse development. (Right half: steady-state situation)

The high gain of organic dyes allows the passive mode-locking with cw argon-ion and krypton-ion lasers $[347,348,22,208,212]$. Generally double $Z$-folded cavities with separate gain and absorber jets are used in linear (standing wave) [217-218] or ring resonators [206]. In early experiments dye cells were used instead of jets [219, 347, 348]. Sometimes the lasing dye and the saturable absorber are mixed and only a single jet is used [218]. Frequency tuning is achieved with wedges, prisms, etalons, or birefringent filters. The pulse repetition rate is of the order of $100 \mathrm{MHz}$ and the average output power is several tens of milliwatt (single pulse energy $\sim 100 \mathrm{pJ}$ ).

Using various lasing dyes and saturable absorbers the wavelength region between 460 and $974 \mathrm{~nm}$ (with gaps) has been covered by $\mathrm{cw}$ passive mode-locking. The performance data are collected in Table 3. In simple linear resonators pulse durations down to $150 \mathrm{fs}$ have been achieved [220]. The femtosecond pulse generation could be stabilized by mixing a slow and fast saturable absorber $[221,253]$. Pulse durations down to $340 \mathrm{fs}$ were reported [253]. In a linear antiresonant ring-cavity pulses with durations down to $130 \mathrm{fs}$ were generated [233]. In a linear colliding pulse mode-locked (linear CPM) laser-pulse duration down to $50 \mathrm{fs}$ were obtained (absorber jet thickness $d_{\text {jet }}=50 \mu \mathrm{m}$, gain jet thickness $100 \mu \mathrm{m}$ ) [223]. In CPM ring lasers the shortest pulse duration achieved was $47 \mathrm{fs}$ [225]. Transient grating effects in thin saturable absorber jets $\left(d_{\text {jet }} \leqslant c_{0} \Delta t_{L} / n_{A}, n_{A}\right.$ refractive index of absorber, $d_{\text {jet }} \leqslant 10 \mu \mathrm{m}$ for $\Delta t_{L}=50 \mathrm{fs}$ ) of CPM lasers stabilize the mode-locking [206, 225-228] and facilitate the extremely short pulse generation.

The short pulses in the resonator are chirped by phase changes in the dielectric mirrors [299-231], selfphase modulation [232-235] and group-velocity dispersion [235] in the optical components. Chirp compensation in the resonator has been achieved by insertion of glass plates [236, 237], prism pairs [222, 224, 238, 239], and Gires-Tournois interferometers $[197,240]$. For a prism-pair compensated linear resonator pulse durations down to $120 \mathrm{fs}$ were reported [249]. In a linear antiresonant ring cavity with intracavity prisms pulses with duration down to $50 \mathrm{fs}$ were generated [224]. Intracavity balancing of self-phase modulation, group-velocity dispersion, saturable absorption, and saturable gain allowed the generation of pulses as short as $27 \mathrm{fs}[241,242]$. The external combination of optical fibers (spectral broadening, chirp formation) and diffraction gratings (compression) offers the possibility to shorten the generated pulses [243-245]. Using an optical fiber and a combination of two prism pairs and a grating pair, pulse durations of $6 \mathrm{fs}$ - so far the shortest pulses - have been achieved [246].

The passive mode-locking of a color-center laser has been demonstrated recently [207]. $\mathrm{A}_{2}^{+}: \mathrm{LiF}$ crystal was pumped with a cw chopped krypton-ion laser. An IR 140 dye solution was used as saturable absorber. In a colliding-pulse mode-locking arrangement pulses were generated at wavelengths around $870 \mathrm{~nm}$ with durations down to $390 \mathrm{fs}$. Suggestions are made to extend the technique to $\mathrm{F}_{2}^{+}: \mathrm{NaF}$ and $\mathrm{F}_{2}^{+}: \mathrm{NaCl}$ crystals and other saturable absorbers. $\mathrm{A}$ tuning range between 1.0 and $1.7 \mu \mathrm{m}$ is expected.

Passive mode-locking of $\mathrm{cw}$ semiconductor diode lasers was achieved by putting the diode in an external resonator. An unpumped pn region is used as saturable absorber $[270,271]$. Recently a radiation-damaged multiple quantum well structure $(\mathrm{AlGaAs} / \mathrm{GaAs})$ has been successfully applied for passive mode-locking $\left(\tau_{A} \simeq 150 \mathrm{ps}, \tau_{G} \simeq 400 \mathrm{ps}\right)$ [117]. Pulse durations down 
Table 3. Cw passively and hybridly mode-locked dye lasers

\begin{tabular}{|c|c|c|c|c|c|c|}
\hline $\mathrm{Dye}^{\mathrm{a}}$ & Absorber $^{\mathbf{a}}$ & $\begin{array}{l}\text { Tuning } \\
\text { range } \\
{[\mathrm{nm}]}\end{array}$ & $\begin{array}{l}\text { Shortest } \\
\text { duration } \\
{[\mathrm{fs}]}\end{array}$ & $\begin{array}{l}\text { Pump } \\
\text { source }\end{array}$ & Resonator & Ref. \\
\hline \multicolumn{7}{|l|}{ Passively mode-locked } \\
\hline Coumarin 102 & DOCI & $\sim 460$ & 580 & $\mathrm{UVAr}^{+}$ & lin, 2 jets & [249] \\
\hline Rhodamine 110 & $\begin{array}{l}\text { HICI } \\
\text { DASBTI } \\
\text { DASBTI } \\
\text { DASBTI } \\
\text { HICI }\end{array}$ & $\begin{array}{l}553-570 \\
553-570 \\
583 \\
583 \\
585\end{array}$ & $\begin{array}{r}152 \\
210 \\
120 \\
70 \\
<100\end{array}$ & $\begin{array}{l}\mathrm{Ar}^{+} \\
\mathrm{Ar}^{+} \\
\mathrm{Ar}^{+} \\
\mathrm{Ar}^{+} \\
\mathrm{Ar}^{+}\end{array}$ & $\begin{array}{l}\text { lin, } 2 \text { jets } \\
\text { lin, } 2 \text { jets } \\
\text { bal, lin, } 2 \text { jets } \\
\text { bal, ring CPM } \\
\text { bal, ring CPM }\end{array}$ & $\begin{array}{l}{[220]} \\
{[220]} \\
{[249]} \\
{[249]} \\
{[249]}\end{array}$ \\
\hline Rhodamine 6G & $\begin{array}{l}\text { DASBTI } \\
\text { DQOCI } \\
\text { DODCI + DQOCI }\end{array}$ & $\begin{array}{l}570-600 \\
583-584 \\
586-592 \\
619-621\end{array}$ & $\begin{array}{l}520 \\
100 \\
100\end{array}$ & $\begin{array}{l}\mathrm{Ar}^{+} \\
\mathrm{Ar}^{+} \\
\mathrm{Ar}^{+}\end{array}$ & $\begin{array}{l}\text { lin, } 2 \text { jets } \\
\text { lin CPM } \\
\text { lin CPM }\end{array}$ & $\begin{array}{l}{[250]} \\
{[223]} \\
{[223]}\end{array}$ \\
\hline & $\begin{array}{l}\text { DODCI } \\
\text { DODCI } \\
\text { cresyl violet } \\
\text { DODCI + malachite } \\
\quad \text { green }\end{array}$ & $\begin{array}{l}590-610 \\
598-615 \\
610-620 \\
608-614\end{array}$ & $\begin{array}{l}400 \\
300 \\
900 \\
340\end{array}$ & $\begin{array}{l}\mathrm{Ar}^{+} \\
\mathrm{Ar}^{+} \\
\mathrm{Ar}^{+} \\
\mathrm{Ar}^{+}\end{array}$ & $\begin{array}{l}\text { lin, } 1 \text { jet } \\
\text { lin, } 1 \text { jet }+1 \text { c.cell } \\
\text { lin, } 1 \text { jet }+1 \text { c.cell } \\
\text { lin, } 2 \text { jets }\end{array}$ & $\begin{array}{l}{[251]} \\
{[219]} \\
{[252]} \\
{[253]}\end{array}$ \\
\hline & $\begin{array}{l}\text { DODCI } \\
\text { DODCI } \\
\text { DODCI } \\
\text { DODCI } \\
\text { DODCI } \\
\text { DODCI }\end{array}$ & $\begin{array}{l}618 \\
615 \\
615 \\
612-630 \\
612-622\end{array}$ & $\begin{array}{r}47 \\
27 \\
6 \\
130 \\
50 \\
50\end{array}$ & $\begin{array}{l}\mathrm{Ar}^{+} \\
\mathrm{Ar}^{+} \\
\mathrm{Ar}^{+} \\
\mathrm{Ar}^{+} \\
\mathrm{Ar}^{+} \\
\mathrm{Ar}^{+}\end{array}$ & $\begin{array}{l}\text { ring CPM } \\
\text { bal, ring CPM } \\
\text { ring CPM, ext.comp. } \\
\text { lin A.R. } \\
\text { bal, lin A.R. } \\
\text { lin CPM }\end{array}$ & $\begin{array}{l}{\left[\begin{array}{ll}225 & 227\end{array}\right]} \\
{[241,242]} \\
{[246]} \\
{[233]} \\
{[224]} \\
{[223]}\end{array}$ \\
\hline Rhodamine B & $\begin{array}{l}\text { DQTCI } \\
\text { cresyl violet }\end{array}$ & $\begin{array}{l}616-658 \\
610-620\end{array}$ & $\begin{array}{r}220 \\
3000\end{array}$ & $\begin{array}{l}\mathrm{Ar}^{+} \\
\mathrm{Ar}^{+}\end{array}$ & $\begin{array}{l}\operatorname{lin}, 2 \text { jets } \\
\text { lin, } 1 \text { jet }+1 \text { c.cell }\end{array}$ & $\begin{array}{l}{[254]} \\
{[252]}\end{array}$ \\
\hline $\begin{array}{l}\text { Rhodamine } 6 G+ \\
\text { Sulforhodamine } 101\end{array}$ & $\begin{array}{l}\text { DQTCI } \\
\text { DCI' }^{\prime}\end{array}$ & $\begin{array}{l}652-681 \\
652-694\end{array}$ & $\begin{array}{l}120 \\
240\end{array}$ & $\begin{array}{l}\mathrm{Ar}^{+} \\
\mathrm{Ar}^{+}\end{array}$ & $\begin{array}{l}\text { lin, } 2 \text { jets } \\
\text { lin, } 2 \text { jets }\end{array}$ & $\begin{array}{l}{[255]} \\
{[255]}\end{array}$ \\
\hline $\begin{array}{l}\text { DCM } \\
\text { Rhodamine } 700\end{array}$ & $\begin{array}{l}\text { DQTCI } \\
\text { DOTCI } \\
\text { DOTCI+ DCI } \\
\text { HITCI }\end{array}$ & $\begin{array}{l}655-673 \\
727-740 \\
740 \\
762-778\end{array}$ & $\begin{array}{r}680 \\
1000 \\
350 \\
850\end{array}$ & $\begin{array}{l}\mathrm{Ar}^{+} \\
\mathrm{Kr}^{+} \\
\mathrm{Kr}^{+} \\
\mathrm{Kr}^{+}\end{array}$ & $\begin{array}{l}\text { lin, } 2 \text { jets } \\
\text { lin, } 2 \text { jets } \\
\text { lin, } 2 \text { jets } \\
\text { lin, } 2 \text { jets }\end{array}$ & $\begin{array}{l}{[256]} \\
{[257]} \\
{[257]} \\
{[256]}\end{array}$ \\
\hline \multicolumn{7}{|l|}{ Hybridly mode-locked } \\
\hline Disodium fluorescein & Rhodamine B & $535-575$ & 450 & m.l.Ar ${ }^{+}$ & 1 jet, lin & {$[258]$} \\
\hline Rhodamine 110 & $\begin{array}{l}\text { Rhodamine B } \\
\text { DODCI } \\
\text { DASBTI }\end{array}$ & $\begin{array}{l}545-585 \\
561 \\
560\end{array}$ & $\begin{array}{l}250 \\
580 \\
283\end{array}$ & $\begin{array}{l}\text { m.l.Ar }{ }^{+} \\
\text {m.l.Ar } \\
\text { Nd:YAG }\end{array}$ & $\begin{array}{l}1 \text { jet, lin } \\
1 \text { jet, lin } \\
2 \text { jets, bal, lin }\end{array}$ & $\begin{array}{l}{[258]} \\
{[258]} \\
{[259]}\end{array}$ \\
\hline Rhodamine 6G & $\begin{array}{l}\text { DODCI + DQOCI } \\
\text { DODCI } \\
\text { DODCI } \\
\text { DODCI } \\
\text { DODCI } \\
\text { Pinacyanol } \\
\text { DODCI } \\
\text { DQOCI }\end{array}$ & $\begin{array}{l}583 \\
622 \\
574-611 \\
595-620 \\
615-625 \\
590-625 \\
620 \\
615\end{array}$ & $\begin{array}{c}69 \\
<150 \\
300 \\
85 \\
130 \\
160 \\
100,60 \\
70\end{array}$ & $\begin{array}{l}\text { Nd:YAG } \\
\text { Nd:YAG } \\
\text { m.l.Ar } \\
\text { Nd:YAG } \\
\text { m.l.Ar } \\
\text { m.l.Ar } \\
\text { m.l.Ar } \\
\text { Nd:YAG }\end{array}$ & $\begin{array}{l}2 \text { jets, bal, lin } \\
2 \text { jets, bal, lin } \\
1 \text { jet, lin } \\
2 \text { jets, lin A.R. } \\
2 \text { jets, lin A.R. } \\
2 \text { jets, lin A.R. } \\
2 \text { jets, ring CPM } \\
1 \text { jet, lin }\end{array}$ & $\begin{array}{l}{[222]} \\
{[222]} \\
{[299]} \\
{[260]} \\
{[261]} \\
{[261]} \\
{[262,268]} \\
{[263]}\end{array}$ \\
\hline Rhodamine B & $\begin{array}{l}\text { DTDCI } \\
\text { Oxazine } 720\end{array}$ & $\begin{array}{l}628 \\
649\end{array}$ & $\begin{array}{l}320 \\
187\end{array}$ & $\begin{array}{l}\text { Nd:YAG } \\
\text { Nd:YAG }\end{array}$ & $\begin{array}{l}2 \text { jets, bal, lin } \\
2 \text { jets, bal, lin }\end{array}$ & $\begin{array}{l}{[264]} \\
{[264]}\end{array}$ \\
\hline $\begin{array}{l}\text { Rhodamine } 101 \\
\text { Sulforhodamine } 101\end{array}$ & $\begin{array}{l}\text { DQTCl } \\
\text { DQTCI }\end{array}$ & $\begin{array}{l}675 \\
675\end{array}$ & $\begin{array}{l}59 \\
55\end{array}$ & $\begin{array}{l}\text { Nd:YAG } \\
\text { Nd:YAG }\end{array}$ & $\begin{array}{l}2 \text { jets, bal, lin } \\
2 \text { jets, bal, lin }\end{array}$ & $\begin{array}{l}{[264]} \\
{[264]}\end{array}$ \\
\hline Pyridine 1 & DDI & 695 & 103 & Nd:YAG & 2 jets, bal, lin & [265] \\
\hline Pyridine 2 & $\begin{array}{l}\text { DDI } \\
\text { DOTCI }\end{array}$ & $\begin{array}{l}733 \\
733\end{array}$ & $\begin{array}{l}263 \\
263\end{array}$ & $\begin{array}{l}\text { Nd:YAG } \\
\mathrm{Nd}: Y A G\end{array}$ & $\begin{array}{l}2 \text { jets, bal, lin } \\
2 \text { jets, bal, lin }\end{array}$ & $\begin{array}{l}{[265]} \\
{[265]}\end{array}$ \\
\hline
\end{tabular}


Table 3 (continued)

\begin{tabular}{lllllll}
\hline Dye $^{\mathrm{a}}$ & Absorber & $\begin{array}{l}\text { Tuning } \\
\text { range } \\
{[\mathrm{nm}]}\end{array}$ & $\begin{array}{l}\text { Shortest } \\
\text { duration } \\
{[\mathrm{fs}]}\end{array}$ & $\begin{array}{l}\text { Pump } \\
\text { source }\end{array}$ & Resonator & Ref. \\
\hline Oxazine 725 & HITCI & $750-780$ & 800 & m.L.Kr & $\begin{array}{l}\text { 1 jet, lin, } \\
\text { cavity-dumped }\end{array}$ \\
Oxazine 750 & HDITC-perchlorate & $750-835$ & 800 & m.L.Kr & 1 jet, lin & {$[266]$} \\
Styril 8 & HITCI & 800 & 70 & Nd:YAG & 2 jets, bal, lin & {$[265]$} \\
Styril 9 & IR 140 & $840-880$ & 65 & m.L.Ar & 2 jets, ring CPM & {$[268]$} \\
Styril 14 & IR 140 & $800-840$ & 137 & Nd:YAG & 2 jets, bal, lin & {$[265]$} \\
& DaQTeC & 974 & 228 & Nd:YAG & 2 jets, bal, lin & {$[269]$} \\
\hline
\end{tabular}

$\mathrm{Ar}^{+}: \mathrm{cw}$ argon ion laser. $\mathrm{Kr}^{+}: \mathrm{cw}$ krypton ion laser. $\mathrm{Nd}: \mathrm{YAG}$ : frequency doubled cw mode-locked Nd:YAG laser. $\mathrm{m} . \mathrm{L} . \mathrm{Ar}{ }^{+}:$modelocked $\mathrm{cw}$ argon ion laser. m.L.Kr ${ }^{+}$: mode-locked cw krypton ion laser. lin: linear resonator. bal: prism balanced resonator. CPM: colliding pulse mode-locked laser. ext.comp.: externally compressed. A.R.: anti-resonator ring colliding pulse arrangement a Dye and absorber data are found in [213,214]

to $1.6 \mathrm{ps}$ have been obtained. The pulses had a positive group velocity dispersion and could be compressed externally with a grating-prism pair down to $0.8 \mathrm{ps}$ [272].

Rare-gas halide excimer lasers are powerful light sources in the UV spectral region [273]. Passive modelocking of discharge-pumped excimer lasers has been achieved for $\mathrm{XeCl}\left(\lambda_{L}=308 \mathrm{~nm}\right.$, absorber BBQ, duration $\left.\Delta t_{L}=2 \mathrm{~ns}\right)$ [274] and $\mathrm{KrF}\left(\lambda_{L}=248.5 \mathrm{~nm}\right.$, absorbers: 7-diethylamino-4-methylcoumarin, $p$-terphenyl, and aurimine $D, \Delta t_{L} \leqq 2 \mathrm{~ns}$ ) [275]. A series of saturable absorbers have been investigated [50, 277, 278]. The excited-state absorption and the dye dissociation and fragmentation are problems for UV saturable absorbers. In high-power excimer lasers the nonlinear absorption of the solvent (mainly two-photon absorption) may act against dye bleaching.

$\mathrm{HeNe}$ lasers have been $\mathrm{cw}$ mode-locked at $\lambda_{L}=632.8 \mathrm{~nm}$ with $\mathrm{Ne}\left(\Delta t_{L} \simeq 330 \mathrm{ps}\right)[164]$ and various saturable dyes (cresyl voilet, Nile blue, Nile blue A,

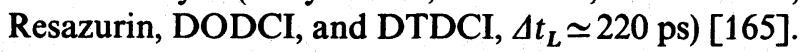
Passive mode-locking of an argon ion laser was carried out with rhodamine 6G [169].

The saturable absorbers themselves may act as active media. Using proper mirror reflectivities the simultaneous ultrashort pulse formation of the emissions of the gain medium and of the absorber medium occurs $[248,344]$. The $\mathrm{cw}$ passive double modelocking has been achieved with rhodamine $6 \mathrm{G}\left(\lambda_{L, 1}\right.$ around $580 \mathrm{~nm})$ and cresyl violet $\left(\lambda_{L, 2}\right.$ around $\left.640 \mathrm{~nm}\right)$ $[247,345,346]$. Passive double mode-locking is also reported for a $\mathrm{HeNe}$ laser with several saturable dyes [165] and an argon ion laser with rhodamine 6G [169].

\subsection{Hybrid Mode-Locking}

For low-gain lasers the passive mode-locking is often combined with active loss modulation. For high-gain lasers the passive mode-locking and the synchronous pumping are combined.

a) Low-Gain Active Media. The simultaneous active and passive mode-locking of low-gain lasers is illustrated in Fig. 6. The laser oscillator (Fig. 6a) consists of the active medium, the saturable absorber cell, and the active loss modulator (generally an acousto-optic modulator [279-281]). For constant pumping (Fig. 6b) the upper-laser-level population (Fig. 6c) remains practically unchanged within a round-trip time $t_{R}$. As long as the circulating radiation intensity in the oscillator is well below the saturation intensity $I_{S}^{A}$ of the saturable absorber, the transmission of the saturable absorber is equal to the small-signal transmission $T_{0}$, and the mode-locking is performed by the active loss modulator (left half of Fig. 6). In the steady-state region (right half of Fig. 6) an intense pulse has been built up. It bleaches the saturable absorber. The active loss modulation causes mode-locking even at low intensities $\left(I_{L}<I_{S}^{A}\right)$. The passive mode-locking shortens the generated circulating pulse. The combined active-passive mode-locking stabilizes the modelocking dynamics. It allows the synchronization of lasers.

The active-passive mode-locking is widely applied for solid-state lasers (Nd:YAG [282-285], Nd:glass [136, 286-290, 328, 332], ruby [291]). The active and passive mode-locking may be combined with cavitydumping [285]. A theoretical investigation of the active-passive mode-locking is presented in [283, 292]. 
(a)

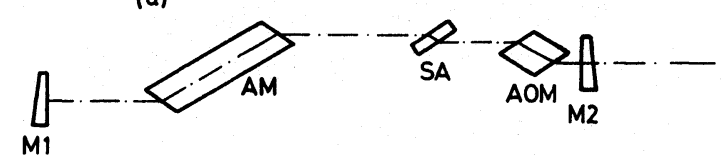

J

(b)
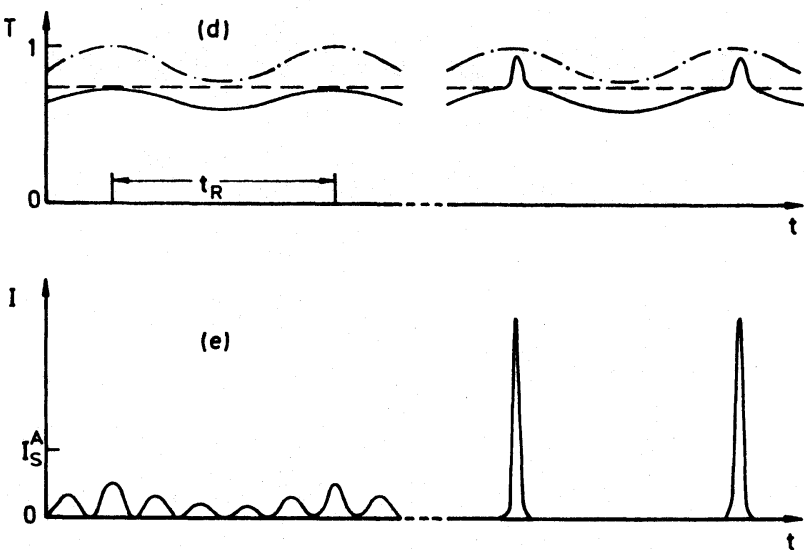

Fig. 6a-e. Hybridly mode-locked low-gain laser. (a) Linear resonator arrangement of an active-passive mode-locked laser. (M1, M2: laser mirrors, AM: active medium, SA: saturable absorber. AOM: acousto-optical modulator).(b) Pump rate $J$. (c) Upper laser level population $N_{u^{*}}$ (d) Temporal light transmission. Dashed curve, saturable absorber. (Dash-dotted curve: acoustooptical modulator, solid curve: total transmission through absorber and acousto-optical modulator). (e) Temporal pulse development. (b-e) Left half: early stage of pulse development. Right half: steady state situation

Besides the active-passive mode-locking with acousto-optic modulators other hybrid mode-locking techniques have been developed. Self-injected (cavityflipped) passively mode-locked lasers have a Pockelscell shutter and an absorber cell inside the resonator $[293,294]$. The voltage across the Pockels cell is varied step-wise in a well defined sequence. First inversion is accumulated (low Q-value), then the resonator Q-factor is switched to a high value and an intense laser radiation is built up. Before inversion depletion the radiation in the cavity is dumped for a period less than the round-trip time. The remaining pulse in the cavity (seeding pulse) is amplified by the gain medium and shortened by the nonlinear transmission through the saturable absorber. Towards the end of the pulse development the generated pulse is cavity-dumped. The self-injection and passive mode-locking has been applied to $\mathrm{Nd}$ : lasers [293, 294].

The simultaneous passive and kinematic modelocking (one laser mirror is vibrated) of $\mathrm{cw} \mathrm{Nd:YAG}$ lasers is analyzed in [295, 296].

The synchroneous pumping of a germaniumswitch with a mode-locked $\mathrm{Nd}$ : glass laser allowed the extraction of picosecond light pulses from a TEA-CO laser [297,298]. The transparent $\mathrm{Ge}$ at $10.6 \mu \mathrm{m}$ is made highly reflective by the large free-carrier generation with $1.06 \mu \mathrm{m}$ pulses.

b) High-Gain Active Media. The most common technique of hybrid mode-locking of dye lasers is the simultaneous synchronous pumping and passive mode-locking. The lasing dye and the saturable dye may be circulated through two separate jets (Fig. 7a) [222, 259-262, 264, 265, 268, 269] or may be mixed and pumped through one jet [258, 263, 266, 267, 299]. A contacted dye cell for the saturable absorber is used in [300].

The synchronous pumping and passive modelocking is illustrated in Fig. 7. A mode-locked pump laser inverts the dye molecules in the lasing dye jet. The round-trip time of the synchronously pumped laser cavity has to be adjusted accurately to the pulse separation of the pump laser train [123, 301, 302]. The pulsed excitation of Fig. 7b populates the upper laser level according to Fig. 7c. At an early stage of modelocking (left half) the upper laser level population decays with the fluorescence lifetime $\tau_{G}$. This lifetime has to be less than the cavity round-trip time $\left(\tau_{G}<t_{R}\right)$ in order to achieve mode-locking by synchronous pumping (otherwise only passive mode-locking occurs). As soon as the peak intensity of the circulating radiation at the saturable absorber jet approaches the saturation intensity $I_{S}^{A}$, the transmission through the absorber increases and the passive mode-locking shortens the pulses generated already by the synchronous pumping.

The performance data of synchronously pumped and passively mode-locking cw dye lasers are collected in Table 3. A wavelength region between 535 and $974 \mathrm{~nm}$ is covered (with gaps).

The synchronous pumping of colliding pulse mode-locked ring dye lasers was studied in $[262,268$, 303]. In [303] the distance between the gain jet and the absorber jet is exactly a quarter of the ring perimeter. The pump pulse separation is half the dye laser roundtrip time $t_{R}$. The dye-laser pulses generated by subsequent pulses collide in the absorber jet. In [262, 268] the distance between the gain jet and the absorber jet is set to one fifth of the perimeter. The gain jet is pumped by an asymmetric sequence of pump pulses at times $t=0$, $3 / 5 t_{R}, t_{R}, 8 / 5 t_{R}, 2 t_{R}, \ldots$ This sequence is obtained with a 
(a)
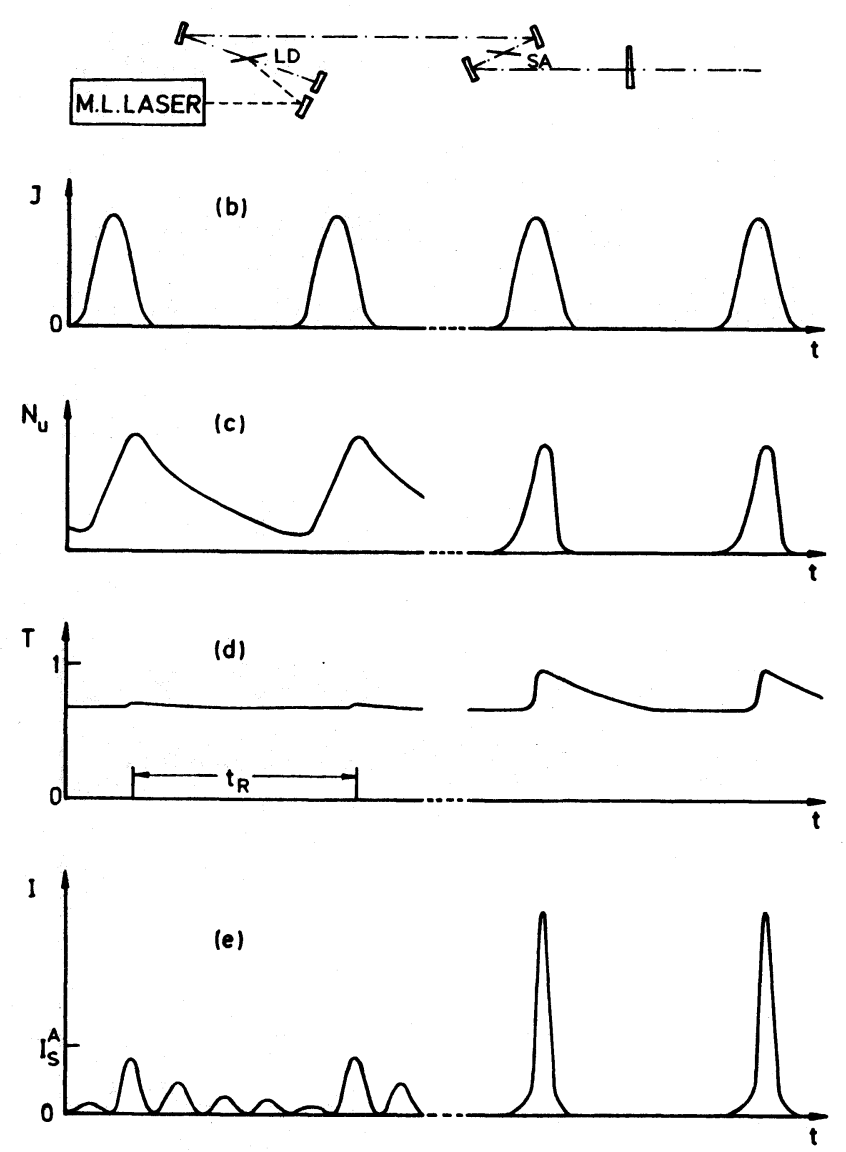

Fig. 7a-e. Hybridly mode-locked high-gain laser. (a) Experimental setup of a synchronously pumped and passively modelocked laser with two jets in the resonator. LD: amplifying dye jet, SA: saturable absorber jet. (b) Pump rate $J$. (c) Upper laser level population $N_{u}$. (d) Transmission through saturable absorber. (e) Temporal pulse development. (b-e) Left half: early stage of pulse development. Right half: steady-state situation

beam splitter and an optical delay line. Dye laser pulses generated by subsequent pump pulses collide in the absorber jet.

The synchronous pumping in linear cavities with colliding pulse mode-locking in an anti-resonant ring is described in [261]. Cavity-dumping of hybridly mode-locked lasers is used in $[266,304]$ to increase the output-pulse energy (for cavity dumping of cw passively mode-locked lasers, see [218]). Hybridly modelocked lasers are synchronized easily to other lasers.

The intracavity $[222,259,264,265,268,269]$ and extracavity [317] pulse compression methods, mentioned in Sect. 3.1b for passively mode-locked lasers, are also applied to hybrid mode-locked lasers.

In the laser systems mentioned above, cw modelocked lasers were used for synchronous pumping. Recently femtosecond dye laser pulses were generated by passive mode-locking and synchronous pumping with prolonged second harmonic pulse trains of a passively mode-locked $\mathrm{Nd}$ :glass laser [318]. $90 \mathrm{fs}$ pulses of $100 \mathrm{~nJ}$ energy could be generated. A singlestage amplifier produced single pulses of $150 \mathrm{fs}$ duration and $10 \mu \mathrm{J}$ energy. The amplified pulses were compressed to $68 \mathrm{fs}$ with a grating pair. In [319] $0.8 \mathrm{ps}$ pulses of $1.6 \mu \mathrm{J}$ energy have been generated in a synchronously pumped dye laser combined with an external saturable absorber-amplifier compressor (Sect. 5.2). The synchronous pumping was achieved with a pulsed frequency-doubled passively modelocked Nd:YAG laser.

The cw passively and hybridly mode-locked dye lasers generate single pulse energies in the region of $0.1 \mathrm{~nJ}$. Various amplification schemes have been developed to amplify - at a reduced repetition rate - the pulses to the $\mu \mathrm{J}$ and $\mathrm{mJ}$ region [212]. $\mathrm{N}_{2}$ lasers [251], Nd:YAG lasers [167, 305-310], copper-vapor lasers [276, 311,312], and excimer lasers [313-315] are used for pumping the amplifier dye cells. $12 \mathrm{~nJ}$ pulses of 100 fs duration could be generated at a repetition rate of $3 \mathrm{MHz}$ with a cavity dumped argon ion laser as a pump source for the amplifier [316].

Besides the synchronous pumping of the active medium, the synchronous pumping of the saturable absorber was applied to mode-lock and synchronize a slave oscillator to a master oscillator [320,321]. A similar technique uses picosecond pulse trains to open ultrahigh-speed semiconductor switches [322] which transmit high-voltage pulse trains to Pockels-cell modulators of lasers that should be mode-locked. This technique was applied to mode-lock a $\mathrm{XeCl}$ excimer laser [323] and a GaAs/GaAlAs semiconductor laser [324].

The active loss modulation with an acousto-optic modulator may also be combined with the passive mode-locking for the ultrashort-pulse generation in $\mathrm{cw}$ dye lasers [325] and flashlamp-pumped dye lasers [326]. The active loss modulation and passive modelocking of a XeCl-excimer laser allowed the generation of 300 ps pulses [327]. RF pump pulse modulation and passive mode-locking was combined for subpicosecond pulse generation in a semiconductor laser [271].

\subsection{Passive Mode-Locking by Refractive-Index Changes}

A medium with intensity-dependent refractive index placed inside the laser oscillator couples the cavity modes by phase modulation. A theoretical analysis of this mode coupling has been given in [124-126]. Mode-locking experiments were carried out with different optical Kerr media in ruby lasers [128] and $\mathrm{Nd}$ : glass lasers $[127,129,130]$. 
The pulse compression inside an actively modelocked Nd:YAG laser by pulse chirping in a liquid Kerr cell (self-phase modulation) has been reported in [121]. The intracavity pulse compression of chirped pulses in a passively mode-locked laser by the finite spectral gain width of the active medium has been discussed in Sect. 3a [32, 121, 159, 175-178].

The simultaneous action of self-phase modulation and negative group velocity dispersion in synchronously pumped color-center lasers incorporating a glass fiber feedback path led to soliton-pulse formation of adjustable femtosecond duration (soliton laser) $[329,330]$.

\section{Simultaneous Q-Switching and Mode-Locking}

The pulsed passive mode-locking of flashlamppumped solid-state lasers is often called mode-locking of a Q-switched laser [24,331] due to the similarity to Q-switched laser operation. To achieve mode-locking, the spectral gain narrowing elements of Q-switched lasers are removed.

The simultaneous Q-switching and passive modelocking is applied in the mode-locked self-injection lasers described in Sect. 3a [293, 294]. The time jitter in a hybridly mode-locked Nd:glass laser was considerably reduced by simultaneously Q-switching the laser with a mechanical chopper (jitter without chopper $\pm 15 \mu \mathrm{s}$, jitter with chopper $\leqq \pm 300 \mathrm{~ns}$ ) [332].

\section{Pulse Shortening with Saturable Absorbers}

Besides passive mode-locking, the saturable absorbers are employed to suppress background radiation [333], to decouple amplifiers (suppression of amplified spontaneous emission signals) $[276,278,306-311,315$, $334]$ and to shorten light pulses [46, 48, 276, 335-341]. It should be noted that the self-induced ellipse rotation of Kerr liquids between polarizers and retardation plates may be used as well for passive background suppression and gain isolation [328].

\subsection{Pulse Shortening \\ in Master-Slave Oscillator Systems}

A master-slave oscillator arrangement for short-pulse generation is illustrated in Fig. 8a [336]. The pulse generation starts in a passively mode-locked laser oscillator (active medium AM 1). After an intense pulse has been built up, the pulse polarization is rotated $90^{\prime \prime}$ with Pockels cell PC1 and the pulse continues to circulate in the slave oscillator (active medium AM 2). The low saturable-absorber transmission of the slave

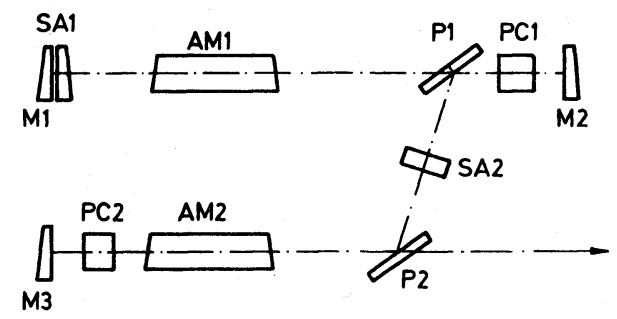

(a)

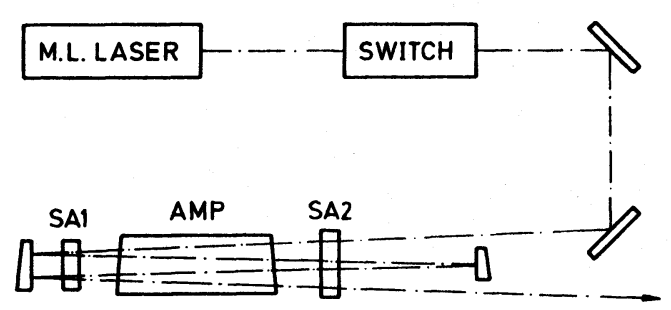

(b)

Fig. 8. (a) Pulse shortening in master-slave oscillator. (AM1: active medium of master oscillator. AM2: active medium of slave oscillator. P1, P2: polarizers. PC1, PC2: Pockels cells, SA1, SA2: saturable absorber cells, M1-M3: laser mirrors). (b) Pulse shortening in multi-pass absorber-amplifier system. (SA1, SA2: saturable absorber, AMP: amplifier medium)

oscillator (regenerative amplifier, absorber cell SA 2) shortens considerably the pulse duration. After several round trips the shortened pulse is switched out by voltage application to the Pockels cell PC2.

With the described system $\mathrm{Nd}$ : glass laser pulses were shortened to $0.9 \mathrm{ps}$. In a similar branchedoscillator setup the $\mathrm{Nd}$ : glass laser pulses were shortened to $0.4 \mathrm{ps}$ [337]. A ring regenerative amplifier was used in [338] for pulse shortening with saturable absorbers. In [339] a $\mathrm{CS}_{2}$ cell was applied for selfswitching from the master to the slave oscillator.

\subsection{Extra-Cavity Pulse Shortening}

The passing of light pulses outside the oscillator through an absorber cell shortens the pulse duration and reduces the background noise $[48,335,340]$. This pulse shortening technique was applied to $\mathrm{Nd}$ :glass lasers [48, 335] ruby lasers [159], excimer lasers [50, 341-343] and dye lasers [319].

A multi-pass absorber-amplifier arrangement is shown in Fig. 8b. Using a similar arrangement passively mode-locked $\mathrm{Nd}$ : glass laser pulses were shortened to $0.5 \mathrm{ps}[48,335]$.

The onset of laser action in excited saturable absorbers shortens the absorption recovery time and 
leads to enhanced pulse shortening [50]. Putting a saturable absorber cell perpendicular into the light path may lead to sufficient feedback for laser action (enhanced amplified spontaneous emission). The combined saturable absorption and enhanced amplified spontaneous emission was applied to shorten excimer laser pulses [50].

\section{Conclusions}

The passive Q-switching and mode-locking as well as the hybrid Q-switching and mode-locking of solidstate lasers, dye lasers, semiconductor lasers, colorcenter lasers, and gas lasers $\left(\mathrm{HeNe}, \mathrm{Ar}^{+}\right.$, iodine, $\mathrm{CO}_{2}$, excimer) has been reviewed. The passive $\mathrm{Q}$-switching and mode-locking techniques are competitive to the active Q-switching and mode-locking techniques. They have the advantage of greater simplicity and they allow the generation of shorter pulse durations.

\section{References}

1. C.R. Giuliano, L.D. Hess: IEEE J. QE-3, 358 (1967)

2. M. Hercher: Appl. Opt. 6, 947 (1967)

3. J.D. Macomber: J. Appl. Phys. 38, 3525 (1967)

4. M. Hercher, W. Chu, D.L. Stockman: IEEE J. QE-4, 954 (1968)

5. L. Huff, L.G. De Shazer: J. Opt. Soc. Am. 60, 157 (1970)

6. H. Schüller, H. Puell: Opt. Commun. 3, 352 (1971)

7. N.J. Frigo: IEEE J. QE-19, 511 (1983)

8. G. Gröninger, A. Penzkofer: Opt. Quant. Electron. 16, 225 (1984)

9. K.P.J. Reddy: Opt. Quant. Electron. 19, 203 (1987)

10. W.G. Wagner, B.A. Lengyel: J. Appl. Phys. 3, 2040 (1963)

11. L.E. Erickson, A. Szabo: J. Appl. Phys. 37, 4953 (1966)

12. B.A. Lengyel: Lasers, 2nd edn. (Wiley, New York 1971)

13. P.G. Kryukov, V.S. Letokhov: Sov. Phys. Usp. 12, 641 (1970)

14. P.G. Kryukov, V.S. Letokhov: IEEE J. QE-8, 766 (1972)

15. P.Ya. Zel'dovich, T.I. Kuznetsova: Sov. Phys. Usp. 15, 25 (1972)

16. D. von der Linde: Appl. Phys. 2, 281 (1973)

17. A. Laubereau, W. Kaiser: Opto-Electron. 6, 1 (1974)

18. H.A. Haus: IEEE J. QE-11, 736 (1975)

19. W.H. Glenn: IEEE J. QE-11, 8 (1975)

20. M.S. Demokan: Mode-Locking in Solid-State and Semiconductor Lasers (Research Studies Press, Chichester 1982)

21. C.P. Ausschnitt: IEEE J. QE-13, 321 (1971)

22. D.J. Bradley: In Ultrahsort Light Pulses, ed. by S.L. Shapiro, Topics Appl. Phys. 18 (Springer, Berlin, Heidelberg 1977) p. 18

23. T.K. Lim, M.M. Denariez-Roberge: Appl. Phys. 15, 439 (1978)

24. G.H.C. New: Proc. IEEE 67, 380 (1979)

25. J. Herrmann, F. Weidner: Opt. Quant. Electron. 11, 119 (1979)

26. J. Herrmann, F. Weidner, B. Wilhelmi: Appl. Phys. 20, 237 (1979)

27. W. Rudolph, H. Weber: SPIE 236, 337 (1980)
28. K.P.J. Reddy: Appl. Phys. 22, 213 (1980)

29. C. Kolmeder, W. Zinth: Appl. Phys. 24, 341 (1981)

30. A. Leitner, M.E. Lippitsch, E. Roschger, F.R. Aussenegg: IEEE J. QE-19, 562 (1983)

31. B. Lü, W. Rudolph, H. Weber: Opt. Commun. 53, 203 (1985)

32. A. Penzkofer, F. Graf: Opt. Quant. Electron. 17, 219 (1985)

33. K.P. Komarov: Opt. Spectrosc. (USSR) 60, 231 (1986)

34. Y.C. Yao, Z.G. Zhang: Appl. Phys. B 40, 157 (1987)

35. G.H.C. New: Opt. Commun. 6, 188 (1972)

36. G.H.C. New: IEEE J. QE-10, 115 (1974)

37. H.A. Haus: IEEE J. QE-12, 169 (1976)

38. Z.A. Yasa, O. Teschke, L.W. Braverman: J. Appl. Phys. 47, 174 (1976)

39. J. Ram, K.P.J. Reddy: Opt. Commun. 33, 323 (1980)

40. J. Herrmann, F. Weidner, B. Wilhelmi: Appl. Phys. B 26, 197 (1981)

41. J. Herrmann, F. Weidner: Appl. Phys. B 27, 105 (1982)

42. N.M. Narovlyanskaya, E.A. Tikhonov: Sov. J. Quant. Electron. 12, 38 (1982)

43. G.H.C. New: Rep. Prog. Phys. 46, 877 (1983)

44. M.S. Stix, E.P. Ippen: IEEE J. QE-19, 520 (1983)

45. D. von der Linde: Appl. Phys. B 39, 201 (1986)

46. N.G. Basov, P.G. Kryukov, V.S. Letokhov, Yu.A. Matveets: Sov. Phys. JETP 29, 830 (1969)

47. L.W. Davis, Y.S. Lin: IEEE J. QE-9, 1135 (1973)

48. A. Penzkofer: Opto-Electron. 6, 87 (1974)

49. R.E. Eason, R.C. Greenhow, J.A.D. Matthew: IEEE J. QE-17, 95 (1981)

50. Ch.G. Christov, I.V. Tomov: Opt. Quant. Electron. 18, 137 (1986)

51. P.R. Hammond: IEEE J. QE-11, 736 (1975)

52. C.D. Decker: Appl. Phys.. Lett. 27, 607 (1975)

53. D.J. Harter, M.L. Shand, Y.B. Band: J. Opt. Soc. Am. 73, 1945 (1983)

54. D.J. Harter, Y.B. Band: In Ultrafast Phenomena IV, ed. by D.H. Auston and K.B. Eisenthal, Springer Ser. Chem. Phys. 38 (Springer, Berlin, Heidelberg 1984) p. 102

55. D.J. Harter, Y.B. Band, E.P. Ippen: IEEE J. QE-21, 1819 (1985)

56. W. Blau, H. Byrne, W.M. Dennis, J.M. Kelly: Opt. Commun. 56, 25 (1985)

57. Y.B. Band, D.J. Harter, R. Bavli: Chem. Phys. Lett. 126, 280 (1986)

58. Y.B. Band, B. Scharf: Chem. Phys. Lett. 127, 381 (1986)

59. D.J. Harter, M.L. Shand, Y.B. Band: J. Appl. Phys. 56, 865 (1984)

60. R.W. Hellwarth: In Lasers, Vol. 1, ed. by A.K. Levine (Dekker, New York 1966) p. 253

61. A. Yariv: Quantum Electronics, 2nd ed. (Wiley, New York 1975)

62. W. Koechner: Solid-State Laser Engineering, 2nd ed., Springer Ser. Opt. Sci. 1 (Springer, Heidelberg, Berlin 1988)

63. A. Penzkofer: Prog. Quant. Electron. (1987) (in press)

64. C.V. Shank, E.P. Ippen: Appl. Phys. Lett. 24, 373 (1974)

65. M.C. Marconi, O.E. Martinez, F.P. Diodati: Opt. Commun. 63, 211 (1987)

66. D. Hull: Appl. Opt. 5, 1342 (1966)

67. Y. LeDuff, P. Peretti, R. Dupeyral: Rev. Phys. Appl. (France) 1, 117 (1966)

68. V. Lupei, A. Lupei, V. Ionită-Mânzatu, S. Georgescu, F. Domsa: Opt. Commun. 48, 203 (1983)

69. T. Kurobori, N. Shoumura, N. Takeuchi: Opt. Commun. 58, 409 (1986) 
70. S.S. Kolyago, V.N. Matrosov, E.V. Pestryakov, V.I. Tranov, Yu.L. Gusev, A.P. Shkadarevich: Sov. J. Quant. Electron. 15, 1653 (1985)

71. M. Tachikawa, K. Tanii, M. Kajita, T. Shimizu: Appl. Phys. B 39, 83 (1986)

72. J.Y. Tsao: Opt. Commun. 60, 225 (1986)

73. V.I. Bezrodnyi, E.A. Tikhonov: Sov. J. Quant. Electron. 16, $1642(1986)$

74. P.P. Sorokin, J.J. Luzzi, J.R. Lankard, G.D. Pettit: IBM J. Res. Dev. 8, 182 (1964)

75. P. Kafalas, J.I. Masters, E.M.E. Murray: J. Appl. Phys. 35, 2349 (1964)

76. B.H. Soffer: J. Appl. Phys. 35, 2551 (1964)

77. D. Röss: Z. Naturforschg. 20a, 696 (1965)

78. M.L. Spaeth, W.R. Sooy: J. Chem. Phys. 48, 2315 (1968)

79. A. Szabo, L.E. Erickson: J. Appl. Phys. 40, 3574 (1969)

80. K. Yoshino, K. Kawabe, Y. Inushi: Jpn. J. Appl. Phys. 8, 1168 (1969)

81. J.F. Giuliani: J. Appl. Phys. 43, 1290 (1972)

82. H. Fujiwara, A. Tomita: Opt. Commun. 20, 29 (1977)

83. H. Jelinkova, K. Hamal, A. Novotny: IEEE J. QE-12, 510 (1976)

84. M. Vrbova: IEEE J. QE-14, 596 (1978)

85. A. Szabo: J. Appl. Phys. 49, 533 (1978)

86. M. Gingras, F. Quellette, M.M. Denariez-Roberge: J. Appl. Phys. 55, 3241 (1984)

87. G. Bret, F. Gires: Appl. Phys. Lett. 4, 175 (1964).

88. R.C. Pastor, H. Kimura, B.H. Soffer: J. Appl. Phys. 42, 3844 (1971)

89. K.H. Drexhage, U.T. Müller-Westerhoff: IEEE J. QE-8, 759 (1972)

90. K.H. Drexhage, G.A. Reynolds: Opt. Commun. 10, 18 (1974)

91. G.A. Reynolds, K.H. Drexhage: J. Appl. Phys. 46, 4852 (1975)

92. R.C. Greenhow, D.M. Goodall, R.W. Eason: Chem. Phys. 83, 445 (1984)

93. Y. Chen, G.Z. Yang, S.J. Gu: Opt. Commun. 63, 94 (1987)

94. Yu.L. Gusev, A.V. Kirpichnikov, V.N. Lisitsyn, S.I. Marennikov: Sov. J. Quant. Electron. 11, 685 (1981)

95. T.T. Basiev, Yu.K. Voron'ko, S.B. Mirov, V.V. Osiko, A.M. Prokhorov: Sov. J. Quant. Electron. 12, 530 (1982)

96. V.A. Rusov, A.I. Stepanov, A.A. Tarasov: Sov. J. Quatn. Electron. 12, 1371 (1982)

97. A.M. Prokhorov: Sov. Phys. Usp. 29, 3 (1986)

98. O.R. Wood, S.E. Schwartz: Appl. Phys. Lett. 11, 88 (1967)

99. P.K. Cheo: In Lasers, Vol. 3, ed. by A.K. Levine and A.J. DeMaria (Dekker, New York 1971) p. 111

100. T.Y. Chang, C.H. Wang, P.K. Cheo: Appl. Phys. Lett. 15, 157 (1969)

101. R.E. Jensen, M.S. Tobin: IEEE J. QE-6, 477 (1970)

102. J.J. Wynne, F. Shimizu: IEEE J. QE-8, 676 (1972)

103. F. Meyer-Bourbonneux, J. Dupré, C. Meyer: Can. J. Phys. 54, 205 (1976)

104. P. Glorieux, D. Dangoisse: IEEE J. QE-21, 1486 (1985)

105. M. Tachikawa, K. Tanii, M. Kajita, T. Shimizu: Appl. Phys. B 39, 83 (1986)

106. M. Tachikawa, K. Tanii, T. Shimizu: J. Opt. Soc. Am. B4, 387 (1987)

107. V.A. Kuz'menko: Sov. J. Quant. Electron. 16, 1667 (1986)

108. R.K. Ahrenkicl, J.F. Figueira, C.R. Phipps, Jr., D.J. Dunlavy, S.J. Thomas, A.J. Sievers: Appl. Phys. Lett. 33, 705 (1978)

109. L. Mandel, L. Wolf: Rev. Mod. Phys. 37, 231 (1965)
110. V.S. Letokhov: Sov. Phys. JETP 28, 562 (1969)

111. H.A. Haus: J. Appl. Phys. 46, 3049 (1975)

112. F. Graf, G. Pleininger, A. Penzkofer: Appl. Phys. B 34, 123 (1984)

113. A. Penzkofer, W. Kaiser: Appl. Phys. Lett. 21, 547 (1972)

114. A.N. Kirkin, A.M. Leontovich, A.M. Mozharovskii: Sov. J. Quant. Electron. 8, 1489 (1978)

115. O.P. Varnavsky, A.N. Kirkin, A.M. Leontovich, R.G Mirzoyan, A.M. Mozharovskiî, I.I. Solomatin: Opt. Commun. 45, 342 (1983)

116. O.P. Varnaosky, A.N. Kirkin, A.M. Leontovich, R.F. Malikov, R.G. Mirzoyan, A.M. Mozharovskii, E.D. Trifonov: Opt. Commun. 46, 131 (1983)

117. P.W. Smith, Y. Silberberg, D.A.B. Miller: J. Opt. Soc. Am. B 2, 1228 (1985)

118. M.A. Lewis, J.T. Knudson: Appl. Opt. 21, 2897 (1982)

119. C.H. Bristo Cruz, F. de Martini, P. Mataloni, E. Plange: IEEE J. QE-19, 573 (1983)

120. L.S. Kornienko, N.V. Kravtsov, A.V. Kir'yanov, V.A. Sidorov, Yu.P. Yatsenko: Sov. J. Quant. Electron. 17, 267 (1987)

121. A.J. Duerinckx, H.A. Vanherzeele, J. van Eck, A.E. Siegman: IEEE J. QE-14, 983 (1978)

122. M.D. Dawson, T.F. Boggess, A.L. Smirl: Opt. Lett. 12, 254 (1987)

123. D. Kühlke, U. Herpers, D. von der Linde: Appl. Phys. B 38, 233 (1985)

124. J.P. Laussade, A. Yariv: IEEE J. QE-5, 435 (1969)

125. J.C. Comly, A. Yariv, E.M. Garmire: Appl. Phys. Lett. 15, 148 (1969)

126. H.A. Haus, Y. Silberberg: IEEE J. QE-22, 325 (1986)

127. L. Dahlström: Opt. Commun. 5, 157 (1972)

128. J. Comly, E. Garmire, J.P. Laussade, A. Yariv: Appl. Phys. Lett. 13, 176 (1968)

129. L. Dahlström: Opt. Commun. 4, 214 (1971)

130. L.E. Dahlström: IEFE J. QE-13, 317 (1977)

131. D.J. Bradley, G.H.C. New, S.J. Caughey: Opt. Commun. 2, 41 (1970)

132. L. Horowitz, P. Papanestor, D.F. Heller: Proc. Int'l. Conf. on Lasers '83, San Francisco, CA(1983)p.170

133. H. Vanherzeele, J.L. van Eck, A.E. Siegman: Appl. Opt. 20, 3484 (1981)

134. V.I. Prokhonenko, E.A. Tikhonov, D.Ya. Yatskiv, E.N. Bushmakin: Sov. J. Quant. Electron. 17, 505 (1987)

135. K.P. Komarov, A.S. Kuch'yanov, V.D. Ugozhayev: Opt. Commun. 57, 279 (1986)

136. P. Heinz, W. Kriegleder, A. Laubereau: Appl. Phys. A 43, 209 (1987)

137. A. Piskarskas et al.: Sov. J. Quant. Electron. (to be published)

138. A.J. De Maria, W.H. Glenn, Jr., M.J. Brienza, M.E. Mack: Proc. IEEE 57, 2 (1969)

139. M.A. Duguay, J.W. Hansen, S.L. Shapiro: IEEE J. QE-6, 725 (1970)

140. G.R. Fleming, I.R. Harrowfield, A.E.W. Knight, J.M. Morris, R.J. Robbins, G.W. Robinson: Opt. Commun. 20, $36(1977)$

141. J.R. Taylor, W. Sibbctt, A.J. Cormier: Appl. Phys. I.ctt. 31, 184 (1977)

142. L.A. Lombre, G. Mainfray, J. Thebault: J. Appl. Phys. 48, 1570 (1977)

143. P.Y. Lu, P.P. Ho, R.R. Alfano: IEEE J. QE-15, 406 (1979)

144. G. Dikchyus, E. Zhilinskas, A. Piskarskas, V. Sirutkaitis: Sov. J. Quant. Electron. 9, 950 (1979) 
145. T.R. Royt: Opt. Commun. 35, 271 (1980)

146. L.S. Goldberg, P.E. Schoen, M.J. Marrone: Appl. Opt. 21, 1474 (1982)

147. B. Bareika, A. Piskarskas, V. Sinkyavichyus, V. Sirutkaîtis: Sov. J. Quant. Electron. 14, 407 (1984)

148. A. Varanavichyus, R. Grigonis, R. Danelyus, A. Piskarskas, D. Podenas: Sov. J. Quant. Electron. 16, 1582 (1986)

149. G.C. Reali: Opt. Commun. 35, 264 (1980)

150. J. Sauteret, M. Novaro: Opt. Commun. 32, 169 (1980)

151. A.N. Zherikhin, V.A. Kovalenko, P.G. Kryukov, Yu.A. Matveets, S.V. Chekalin, O.B. Shatberashvili: Sov. J. Quant. Electron. 4, 210 (1974)

152. V.I. Bezrodnyî, E.A. Tikonov, N.Yu. Nedbaev: Sov. J. Quant. Electron. 16, 796 (1986)

153. M.E. Mack: IEEE J. QE-4, 1016 (1968)

154. R. Cubedu, R. Polloni, C.A. Sacchi, O. Svelto: IEEE J. QE-5, 470 (1969)

155. R. Polloni: IEEE J. QE-8, 428 (1972)

156. M.W. McGeoch: Opt. Commun. 7, 116 (1973)

157. T. Okada, M. Migita, N. Mataga, Y. Sakata, S. Misumi: J. Am. Chem. Soc. 103, 4715 (1981)

158. H. Tashiro, J. Schulz-Hennig, A. Müller: Opt. Commun. 27, 442 (1978)

159. P. Sperber, A. Penzkofer: Opt. Commun. 54, 160 (1985)

160. V.N. Lisitsyn, V.N. Matrosov, V.P. Orekhova, E.V. Pestryakov, B.K. Sevast'yanov, V.I. Trunov, V.N. Zenin, Yu.L. Remigailo: Sov. J. Quant. Electron. 12, 368 (1982)

161. M.I. Demchuk, A.K. Gilev, A.M. Zubaznov, V.P. Mikhailov, A.A. Stavrov, A.P. Shkadarevich:Opt. Commun. 55, 207 (1985)

162. R.S. Taylor, B.K. Garside, E.A. Bullik: IEEE J. QE-14, 532 (1978)

163. P.E. Dyer, D.J. James: Appl. Phys. Lett. 26, 331 (1967)

164. G. Fox, S.E. Schwarz, P.W. Smith: Appl. Phys. Lett. 12, 371 (1968)

165. P.K. Runge: Opt. Commun. 5, 311 (1978)

166. G. Brederlow, E. Fill, K.J. Witte: The High-Power Iodine Laser, Springer Ser. Opt. Sci. 34 (Springer, Berlin, Heidelberg 1983)

167. D. Beaupere, J.C. Farcy: Opt. Commun. 27, 410 (1978)

168. H.J. Polland, T. Elsaesser, A. Seilmeier, W. Kaiser, M. Kussler, N.J. Marx, B. Sens, K.H. Drexhage: Appl. Phys. B 32, 53 (1983)

169. W. Dietel, E. Döpel, D. Kühlke: Opt. Commun. 35, 445 (1980)

170. C. Kolmeder, W. Zinth: Appl. Phys. 24, 341 (1981)

171. A.V. Konyashchenko, I.V. Kryukov, P.G. Kryukov, A.V. Sharkov: Sov. J. Quant. Electron. 17, 511 (1987)

172. L.S. Kornienko, N.V. Kravtsov, V.Ä. Sidorov, Yu.P. Yatsenko: Sov. J. Quant. Electron. 13, 943 (1983)

173. L.S. Kornienko, N.V. Kravtsov, V.A. Sidorov, A.M. Susov, Yu.P. Yatsenko: Sov. J. Quant. Electron. 15, $1566(1985)$

174. R.C. Eckardt, C.H. Lee, J.N. Bradford: Opto-Electron. 6, 67 (1974)

175. D. von der Linde, A.M. Malvezzi: Appl. Phys. B 37, 1 (1985)

176. T. Tomie: Jap. J. Appl. Phys. 24, 1008 (1985)

177. J. Schmidt, F. Reil, A. Penzkofer: Opt. Commun. 38, 427 (1986)

178. D.F. Voss, L.S. Goldberg: Opt. Lett. 11, 210 (1986)

179. E.B. Treacy: Phys. Lett. A 28, 34 (1968)

180. A. Laubereau, D. von der Linde: $Z$. Naturf. 23A, $1626(1970)$

181. M.I. Demchuk, V.P. Mikailov, A.F. Chernyavskii: Bull. Acad. Sci. USSR, Phys. Ser. (USA) 48, 167 (1984)
182. V.A. Babenko, G.G. Dyadyuska, M.A. Kudinova, V.I. Malyshev, Yu.L. Slominskii, A.A. Sychev, A.I. Tolmachev: Sov. J. Quant. Electron. 10, 1035 (1980)

183. B.F. Bareika, R.V. Danelyus, G.A. Dikchyus, G.G. Dyadyusha, A.A. Ishchenko, M.A. Kudinova, A.S. Piskarskas, V.A. Sirutkaitis, A.I. Tolmachev: Sov. J. Quant. Electron. 12, 1485 (1982)

184. R.A. Gadonas, V.V. Bryukvin, V.V. Krasauskas, E.E. Penzina, A.S. Piskarskas, L.M. Sobolev: Opt. Spectrosc. 58, 581 (1985)

185. M.I. Demchuk, E.V. Zharikov, A.M. Zabaznov, I.A. Manichev, V.P. Mikhailov, A.M. Prokhorov, A.P. Shkadarevich, A.F. Chernyakoskii, I.A. Shcherbakov, K.V. Yumashev: Sov. J. Quant. Electron. 17, 266 (1987)

186. W.H. Lowdermilk: In Laser Handbook, Vol. 3, ed. by M.L. Stitch (North-Holland, Amsterdam 1979) p. 361

187. D.E. McCumber, M.D. Sturge: J. Appl. Phys. 34, 1682 (1963)

188. M.A. Duguay, J.W. Hansen: Opt. Commun. 1, 254 (1969)

189. W. Blau, R. Reber, A. Penzkofer: Opt. Commun. 43, 210 (1982)

190. D.N. Dempster, T. Morrow, R. Rankin, G.F. Thompson: Chem. Phys. Lett. 22, 222 (1973)

191. E.G. Arthurs, D.J. Bradley, P.N. Puntambekar, I.S. Ruddock: Opt. Commun. 12, 360 (1974)

192. T. Kushida: Phys. Rev. 185, 500 (1969)

193. A.V. Babushkin, N.S. Vorob'ev, E.V.Zharikov, S.P. Kalitin, V.V. Osiko, A.N. Prokhorov, Yu.N. Serdyuchenko, M.Ya. Shchelev, I.A. Shcherbakov: Sov. Quant. Electron. 16, 428 (1986)

194. D. von der Linde, K.F. Rodgers: IEEE J. QE-9, 960 (1973)

195. B. Kopainsky, W. Kaiser, K.H. Drexhage: Opt. Commun. 32, 451 (1980)

196. F. Graf, A. Penzkofer: Opt. Quant. Electron. 17, 53 (1985)

197. J. Kuhl, J.P. Heppner: IEEE J. QE-22, 182 (1986)

198. B. Fan, T.K. Gustafson: Opt. Commun. 15, 32 (1975)

199. B. Bareika, R. Gadonas, R. Danelyus, V. Sirutkaítis: Sov. J. Quant. Electron. 11, 396 (1981)

200. R.W. Eason, R.C. Greenhow, J.A.D. Matthews: IEEE J. QE-17, 95 (1981)

201. W. Blau, W. Dankesreiter, A. Penzkofer: Chem. Phys. 85 473 (1984)

202. A. Penzkofer, P. Sperber: Chem. Phys. 88, 309 (1984)

203. J.C. Walling, O.G. Peterson, H.P. Jenssen, R.C. Morris, E.W. O'Dell: IEEE J. QE-18, 1302 (1980)

204. E.V. Pestryakov, V.I. Trunov, V.N. Matrosov, V.N. Razvalyaev: Bull. Acad. Sci. USSR, Phys. Ser. (USA) 48, 94 (1984)

205. M.I. Demchuk, V.P. Mikhailov, A.F. Chernyavskii: Bull. Acad. Sci. USSR, Phys. Ser. (USA) 48, 167 (1984)

206. R.L. Fork, B.I. Greene, C.V. Shank: Appl. Phys. Lett. 38 , 671 (1981)

207. N. Langford, K. Smith, W. Sibbett: Opt. Lett. 12, 903 (1987)

208. C.V. Shank, E.P. Ippen: In Dye Lasers, 2nd ed., ed. by F.P. Schäfer Topics Appl. Phys. 1 (Springer, Berlin, Heidelberg 1977) p. 121

209. W. Schmidt, F.P. Schäfer: Phys. Lett. 26A, 558 (1968)

210. E.G. Arthurs, D.J. Bradley, A.G. Roddie: Appl. Phys. Lett. 20, 125 (1972)

211. R. Wallenstein: In Laser Handbook, Vol. 3, ed. by M.L Stitch (North-Holland, Amsterdam 1979) p. 289

212. G.R. Fleming: Chemical Applications of Ultrafast Spectroscopy (Oxford Univ. Press, Oxford 1986) 
213. M. Maeda: Laser Dyes (Academic, Tokyo 1984)

214. U. Brackmann: Lambdachrome Laser Dyes (Lamda Physik, Göttingen 1986)

215. N.N. Narovlyanskaya, E.A. Tikhonov: Sov. J. Quant. Electron. 12, 38 (1982)

216. H. Ansari, A. Dienes, J.R. Whinnery: Opt. Lett. 10, 19 (1985)

217. E.P. Ippen, C.V. Shank, A. Dienes: Appl. Phys. Lett. 21, 348 (1972)

218. C.V. Shank, E.P. Ippen: Appl. Phys. Lett. 24, 373 (1974)

219. I.S. Ruddock, D.J. Bradley: Appl. Phys. Lett. 29, 296 (1976)

220. P.M.W. French, J.R. Taylor: Opt. Lett. 11, 297 (1986)

221. E.P. Ippen, C.V. Shank: Appl. Phys. Lett. 27, 488 (1975)

222. M.D. Dawson, T.F. Boggess, D.W. Gravey, A.L. Smirl: Opt. Commun. 60, 79 (1986)

223. W. Bäumler, A. Penzkofer: To be published

224. J.C. Diels, N. Jamasbi, L. Sarger: In Ultrafast Phenomena $V$, ed. by G.R. Fleming and A.E. Siegman, Springer Ser. Chem. Phys. 46 (Springer, Berlin, Heidelberg 1986) p. 2

225. G.R. Jacobovitz, C.H. Brito Cruz, M.A. Scarparo: Opt Commun. 57, 133 (1986)

226. R.L. Fork, C.V. Shank, R. Yen, C.A. Hirlimann: IEEE J. QF.19, 500 (1983)

227. W. Dietel, J.J. Fontaine, J.C. Diels: Opt. Lett. 8, 4 (1983)

228. D. Kühlke, W. Rudolph, B. Wilhelmi: IEEE J. QE-19, 526 (1983)

229. S. de Silvestri, P. Laporta, O. Svelto: IEEE J. QE-20, 533 (1984)

230. W. Dietel, E. Döpel, K. Hehl, W. Rudolph, E. Schmidt: Opt. Commun. 50, 179 (1984)

231. P. Laporta, V. Magni: Appl. Opt. 24, 2014 (1985)

232. O.E. Martinez, R.L. Fork, J.P. Gordon: Opt. Lett. 9, 156 (1984)

233. J.C. Diels, W. Dietel, J.J. Fontaine, W. Rudolph, B. Wilhelmi: J. Opt. Soc. Am. B 2, 68 (1985)

234. Y. Ishida, K. Naganuma, T. Yajima: IEEE J. QE-21, 69 (1985)

235. B. Wilhelmi, W. Rudolph, E. Döpel, W. Dietel: Optica Acta 32, 1175 (1985)

236. J.J. Fontaine, W. Dietel, J.C. Diels: IEEE J. QE-19, 1467 (1983)

237. W. Dietel, E. Döpel, D. Kühlke, B. Wilhelmi: Opt. Commun. 43, 433 (1982)

238. R.L. Fork, O.E. Martinez, J.P. Gordon: Opt. Lett. 9, 150 (1984)

239. F. Salin, A. Brun: J. Appl. Phys. 61, 4736 (1987)

240. J.P. Heppner, J. Kuhl: Appl. Phys. Lett. 47, 453 (1985)

241. J.A. Valdmanis, R.L. Fork, J.P. Gordon: Opt. Lett. 10, 131 (1985)

242. J.A. Valdmanis, R.L. Fork: IEEE J. QE-22, 112 (1986)

243. B. Nikolaus, D. Grischkowsky: Appl. Phys. Lett. 43, 228 (1983)

244. W.H. Knox, R.L. Fork, M.C. Downer, R.H. Stolen, C.V Shank, J.A. Valdmanis: Appl. Phys. Lett. 46, 1120 (1985)

245. J.G. Fujimoto, A.M. Weiner, E.P. Ippen: Appl. Phys. Lett. 44, 832 (1984)

246. R.L. Fork, C.H. Brito Cruz, P.C. Becker, C.V. Shank: Opt. Lett. 12, 483 (1987)

247. Z.A. Yasa, A. Dienes, J.R. Whinnery: Appl. Phys. Lett. 30 , 24 (1977)

248. K.K. Li, G. Arjavalingam, A. Dienes, J.R. Whinnery: IEEE J. QE-19, 539 (1983)

249. P.M.W. French, J.R. Taylor: V. Int. Symposium of Ultrafast Phenomena in Spectroscopy, Vilnius, USSR (1987)
250. P.M.W. French, M.D. Dawson, J.R. Taylor: Opt. Commun. 56, 430 (1986)

251. Yu.A. Matveets, V.A. Semchishen: Sov. J. Quant. Electron. 9, 503 (1979)

252. I.S. Ruddock: Appl. Opt. 18, 3212 (1979)

253. A. Watanable, H. Tahemura, S. Tanaka, H. Kobayashi, M. Hara: IEEE J. QE-19, 533 (1983)

254. P.M.W. French, J.R. Taylor: Opt. Commun. 58, 53 (1986)

255. P.M.W. French, J.R. Taylor: IEEE J. QE-22, 1162 (1986)

256. P.M.W. French, J.R. Taylor: In Ultrafast Phenomena V, ed. by G.R. Fleming and A.E. Siegman, Springer Ser. Chem. Phys. 46 (Springer, Berlin, Heidelberg 1986) p. 11

257. K. Smith, N. Langford, W. Sibbett, J.R. Taylor: Opt. Lett. 10, 559 (1985)

258. Y. Ishida, K. Naganuma, T. Yajima: Jpn. J. Appl. Phys. 21, L 312 (1982)

259. M.D. Dawson, T.F. Boggess, A.L. Smirl: Opt. Lett. 12, 254 (1987)

260. T. Norris, T. Sizer II, G. Mourou: J. Opt. Soc. Am. B 2, 613 (1985)

261. H. Vanherzeele, R. Torti, J.C. Diels: Appl. Opt. 23, 4182 (1984)

262. M.C. Nuss, R. Lconhardt, W. Zinth: Opt. Lett. 10,16(1985)

263. G.A. Mourou, T. Sizer II: Opt. Commun. 41, 47 (1982)

264. M.D. Dawson, T.F. Boggess, D.W. Garvey, A.L. Smirl: IEEE J. QE-23, 290 (1987)

265. M.D. Dawson, T.F. Boggess, A.L. Smirl: Opt. Lett. 12, 254 (1987)

266. Y. Aoyagi, Y. Segawa, M. Inami, S. Namba: Opt. Commun. 52, 425 (1985)

267. G.W. Fehrenbach, K.J. Gruntz, R.G. Ulbrich: Appl. Phys. Lett. 33, 159 (1978)

268. J. Dobler, H.H. Schultz, W. Zinth: Opt. Commun. 57, 407 (1986)

269. M.D. Dawson, T.F. Boggess, A.L. Smirl: Opt. Lett. 12, 590 (1987)

270. E.P. Ippen, D.J. Eilenberger, R.W. Dixon: Appl. Phys. Lett. 37, 267 (1980)

271. P.P. Vasil'ev, V.N. Morozov, Y.M. Popov, A.B. Sergeev: IEEE J. QE-22, 149 (1986)

272. Y. Silberberg, P.W. Smith: IEEE J. QE-22, 759 (1986)

273. J.J. Ewing: In Laser Handbook, Vol. 3, ed. by M.L. Stitch (North-Holland, Amsterdam 1979) Chap. A4

274. S. Watanabe, M. Watanabe, A. Endoh: Appl. Phys. Lett. 43, 533 (1983)

275. T. Efthimiopoulos, J. Banic, B.P. Stoicheff: Can. J. Phys. 57, 1437 (1979)

276. W.H. Knox, M.C. Downer, R.L. Fork, C.V. Shank: Opt. Lett. 9, 552 (1984)

277. E.M. Vernigor, M.S. Dzhidzhoev, V.M. Mizin, V.T. Platonenko, V.K. Popov, V.K. Shalaev: Sov. J. Quant. Electron. 16, 434 (1986)

278. R.S. Taylor, S. Mihailov: Appl. Phys. B 38, 131 (1985)

279. J. Sapriel: Acousto-Optics (Wiley, Chichester 1979)

280. G.F. Albrecht, L. Lund, D. Smith: Appl. Opt. 22, 1276 (1983)

281. A.E. Siegman, D.J. Kuizenga: Opto-Electron. 6, 43 (1974)

282. M.A. Lewis, J.T. Knudtson: Appl. Opt. 21, 2897 (1982)

283. H.P. Kortz: IEEE J. QE-19, 578 (1983)

284. D. von der Linde, N. Fabricius, M. Kuchartz: CLEO '86, San Francisco, CA, Digest, p. 178

285. M. Glotz, H.J. Eichler: J. Phys. E 20, 1493 (1987)

286. S. Kishida, T. Yamane: Opt. Commun. 18, 19 (1976) 
287. I.V. Tomov, R. Fedosejevs, M.C. Richardson: Opt. Commun. 21, 327 (1977)

288. I.V. Tomov: Rev. Sci. Instrum. 50, 9 (1979)

289. W. Seka, J. Bunkenburg: J. Appl. Phys. 49, 2277 (1978)

290. L.S. Goldberg, P.E. Schoen: IEEE J. QE-20, 628 (1984)

291. G.V. Krivoshchekov, N.G. Nikulin, V.A. Smirnov: Sov. J. Quant. Electron. 5, 1096 (1976)

292. Y.C. Yao, Z.G. Zhang: Appl. Phys. B 40, 157 (1986)

293. C.H. Brito Cruz, F. De Martini, P. Mataloni, E. Plange: IEEE J. QE-19, 573 (1983)

294. W. Krause, F. Völker, H. Weber: Proc. ESA on Space Laser Applications and Technology, Les Diablerets (1984) p. P161

295. L.S. Kornienko, T.V. Klykova, N.V. Kravtsov, V.A. Sidorov, A.M. Susov, Yu.P. Yatsenko: Sov. J. QE-16, 1637 (1986)

296. L.S. Kornienko, N.V. Kravtsov, A.V. Kir'yanov, V.A. Sidorov, Yu.P. Yatsenko: Sov. J. Quant. Electron. 17, 267 (1987)

297. P.B. Corkum: IEEE J. QE-21, 216 (1985)

298. S.A. Jamison, A.V. Nurmikko: Appl. Phys. Lett. 33, 598 (1978)

299. Y. Ishida, T. Yajima, K. Naganuma: Jpn. J. Appl. Phys. 19, L 717 (1980)

300. J.P. Ryan, L.S. Goldberg, D.J. Bradley: Opt. Commun. 27, 127 (1978)

301. B. Couillaud, V. Fossati-Bellani, G. Mitchell: SPIE 533, 46 (1985)

302. V.A. Nekhaenko, S.M. Pershin, A.A. Podshivalov: Sov. J. Quant. Electron. 16, 299 (1986)

303. P.G. May, W. Sibbett, J.R. Taylor: Appl. Phys. B 26, 179 (1981)

304. D.P. Millar, A.H. Zewail: Chem. Phys. 72, 381 (1982)

305. T. Sizer, J.D. Kafka, I.N. Duling, C.W. Gabel, G.A. Mourou: IEEE J. QE-19, 506 (1983)

306. I.N. Duling, T. Norris, T. Sizer, P. Bado, G. Mourou: J. Opt. Soc. Am. B 2, 616 (1985)

307. R.L. Fork, C.V. Shank, R.T. Yen: Appl. Phys. Lett. 41, 223 (1982)

308. Y. Ishida, A. Nakamura, K. Naganuma, T. Yajima: Opt. Commun. 39, 411 (1981)

309. A. Migus, C.V. Shank, E.P. Ippen, R.L. Fork: IEEE J. QE-18, 101 (1982)

310. S.R. Rotman, C. Roxlo, D. Bebelaar, T.K. Yee, M.M. Salour: Appl. Phys. B 28, 319 (1982)

311. D.B. McDonald, C.D. Jonah: Rev. Sci. Instr. 55, 1166 (1984)

312. S. Lavi, G. Bialolanker, M. Amit, D. Belker, G. Erez, E. Miron: Opt. Commun. 60, 309 (1986)

313. J.H. Glownia, G. Arjavalingham, P.P. Sorokin, J.E. Rothenberg: Opt. Lett. 11, 79 (1986)

314. A.P. Schwarzenbach, T.S. Luk, I.A. McIntyre, U. Johann, A. McPherson, K. Boyer, C.K. Rhodes: Opt. Lett. 11, 449 (1986)

315. S. Szatmári, F.P. Schäfer, E. Müller-Horsche, W. Mückenheim: Opt. Commun. 63, 305 (1987)
316. M.C. Downer, R.L. Fork, M. Islam: In Ultrafast Phenomena IV, ed. by D.H. Auston and K.B. Eisenthal, Springer Ser. Chem. Phys. 38 (Springer, Berlin, Heidelberg 1984) p. 27

317. Y. Ishida, T. Yajima: Opt. Commun. 58, 355 (1986)

318. G. Angel, R. Gagel, A. Laubereau: Opt. Commun. 63, 259 (1987)

319. Y. Taira, T. Yajima: Opt. Commun. 29, 115 (1979)

320. E. Lill, S. Schneider, F. Dörr: Opt. Commun. 22, 107 (1977)

321. S. Schneider, E. Lill, F. Dörr: In Picosecond Phenomena, ed. by C.V. Shank, E.P. Ippen, S.L. Shapiro, Springer Ser. Chem. Phys. 4 (Springer, Berlin, Heidelberg 1978) p. 23

322. D. Auston: Appl. Phys. Lett. 26, 101 (1975)

323. G. Reksten, T. Varghese, W. Margulis: Appl. Phys. Lett. 38 513 (1981)

324. E.O. Göbel, J. Kuhl, G. Veith: J. Appl. Phys. 56, 862 (1984)

325. T. Kurobori, Y. Cho, Y. Matsuo: Opt. Commun. 24, 41 (1978)

326. M.D.J. Burgess, R. Fedosejevs, P.A. Jaanimagi, M.C. Richardson: IEEE J. QE-17, 496 (1981)

327. M. Watanabe, S. Watanabe, A. Endoh: Opt. Lett. 2, 638 (1983)

328. K. Sala, M.C. Richardson: J. Appl. Phys. 49, 2268 (1978)

329. L.F. Mollenhauer, R.H. Stolen: Opt. Lett. 9, 13 (1985)

330. F.M. Mitschke, L.F. Mollenhauer: In Ultrafast Phenomena V, ed. by G.R. Fleming and A.E. Siegman, Springer Ser. Chem. Phys. 46 (Springer, Berlin, Heidelberg 1986) p. 58

331. G.H.C. New: IEEE J. QE-14, 642 (1978)

332. H. Schillinger, A. Penzkofer: Opt. Commun. (to be published)

333. J. Wiedmann, A. Penzkofer: Opt. Commun. 25, 226 (1978)

334. S. Szatmári, B. Rácz: Opt. Quant. Electron. 19, 20 (1987)

335. A. Penzkofer, D. von der Linde, A. Laubereau, W. Kaiser: Appl. Phys. Lett. 20, 351 (1972)

336. A. Penzkofer, F. Härtinger, J. Wiedmann: Appl. Phys. B 26 , 239 (1981)

337. F. Graf, J. Schmidt, A. Penzkofer: Opt. Commun. 54, 176 (1985)

338. J. Choi, M.J. Topp: J. Opt. Am. 71, 520 (1981)

339. B.P. Boczar, M.R. Topp: Appl. Opt. 22, 1611 (1983)

340. W. Krause: Opt. Commun. 48, 47 (1983)

341. T. Varghese: Appl. Phys. Lett. 41, 684 (1982)

342. Y.S. Huo, J. Glinsky, X.J. Gu, R.F. Code: Opt. Commun. 51, 181 (1984)

343. Ch.G. Christov, I.V. Tomov, I.V. Chaltakov, V.L. Lyutskanov: Opt. Commun. 52, 211 (1984)

344. Z.A. Yasa: J. Appl. Phys. 46, 4895 (1975)

345. Z.A. Yasa, O. Teschke: Appl. Phys. Lett. 27, 446 (1975)

346. H. Mahr: IEEE J. QE-12, 554 (1976)

347. E.P. Ippen, C.V. Shank, A. Dienes: Appl. Phys. Lett. 21, 348 (1972)

348. F. O’Neill: Opt. Commun. 6, 360 (1972) 